\title{
Dımaşkin En Zor Yılı: Şehrin Moğollar Tarafından İşgali (658/1260)
}

\author{
Harun Yilmaz
}

The Hardest Year of Damascus: The Invasion of the City by the Mongols (658/1260)

Following the invasion of Baghdād in 656 (1258), the Mongols headed further west in Muslim lands. At the time, Ayyūbids controlled Bilād al-Shām while Mamlūks ruled in Egypt, having put an end to Ayyūbid domination ten years earlier. The Mongols' massacres and usurpation, especially when they captured Aleppo, caused great fear and anxiety throughout the region. Therefore, many of the cities in the region, including Damascus, the most important centre of Bilād al-Shām, surrendered to the Mongols without any resistance. The Ayyūbid dynasty collapsed with the Mongols' invasion of Damascus, a city which remained in Mongol hands for about eight months until they were defeated by the Mamlūks in the battle of 'Ain Jālūt. The Mongol invasion led to significant changes in religious, scientific and economic life in Damascus, and changed the political and military structures in the city. The invasion of Damascus caused basically three major developments: High tension in Muslim-Christian relations and the attempt to establish a new social order; building relations with scholars ('ulamä) through appointments to teaching positions, and the reorganization of positions themselves; and finally the migration of people, including scholars, from the city due to insecure conditions. This article deals with the developments that took place in Damascus during the Mongol invasion and the following restoration period, with a special reference to their influence upon the scholarly community of the city.

Key words: Damascus, Ayyūbids, office of chiefqādī, Mongols, 'ulamā’.

\section{Giriș}

Nûreddin Mahmud Zengînnin 569 (1174) yılında vefatından sonra meydana gelen iktidar mücadelelerinden zaferle çıkan Selâhaddîn-i Eyyûbî,

* Yrd. Doç. Dr., Marmara Üniversitesi İlâhiyat Fakültesi (harun.yilmaz@marmara.edu.tr). 
kısa sürede Zengîler'in idaresindeki bütün toprakları kontrol altına alarak Bilâdüşşam ve Mısır'da yaklaşık yüzyıl sürecek Eyyûbî hâkimiyetini kurdu.

Eyyûbîler genel olarak, başında aileye mensup bir sultanın bulunduğu, güç ve otoritelerine göre belirli bölge veya şehirleri kontrol eden melikliklerden oluşmaktaydı. Bu durum melikler arasında bitmek bilmeyen savaşlara, güç ve iktidar mücadelelerine sebep olmaktaydı. Diğer küçük şehirler bir yana Kahire'yle birlikte devletin en önemli merkezi olan Dımaşk, Selâhaddin'in hâkimiyetine girdiği 570 (1174) yılından Moğollar’ın şehri ele geçirip Eyyûbîler'in Dımaşk koluna son verdiği 658’e (1260) kadarki yaklaşık seksen beş yılda on dört melik tarafından idare edildi. ${ }^{1}$

Eyyûbîler uzun yıllar kendi iç mücadeleleriyle uğraşırken varlıklarını tehlikeye düşürecek ciddi bir dış tehditle karşılaşmadılar. Komşuları olan Haçllar her zaman önemli ve canlı bir tehdit unsuru olmaya devam etti. Bununla beraber Selâhaddîn-i Eyyûbînnin 583’te (1187) Kudüs'ü fethiyle sonuçlanan savaşların ardından artık eski güçlerini kaybetmişlerdi. Kuzeyde ise Selçuklular ile zaman zaman askerî çarpışmalar meydana gelse de bu mücadele hiçbir zaman nihaî bir savaşa dönüşmedi. Fakat VII. (XIII.) asrın ortalarına gelindiğinde Eyyûbîler'in yıkımına sebep olan iki önemli olay yaşandı. İlk olarak Mısır'a yönelik VII. Haçlı Seferi meydana geldi. Haçlılar ile mücadeleden zaferle çıkan Eyyûbî sultanının Memlük birlikleri 648'de (1250) el-Melikü'l-Muazzam Turan Şah’’ öldürerek Mısır'daki Eyyûbî hâkimiyetine son verdiler ve Memlükler adıyla bilinen Türk Devleti’ni kurdular. İkinci olarak ise doğu İslam coğrafyasını kasıp kavuran Moğollar’n Bilâdüşşam’a saldırıları başladı.

Moğollar Bilâdüşşam’a girdiklerinde Dımaşk Eyyûbîler'in o dönemki en önemli meliki el-Melikün-Nâsır Yûsuf'un (1236-1260) hâkimiyetinde bulunmakta, yine onun kontrolünde bulunan Halep’te nâibi Turan Şah görev yapmaktaydı. Hama ve Humus gibi Bilâdüşşam’ın diğer şehirleri Eyyûbî ailesinden başka meliklerin kontrolünde olmasına rağmen yine el-MelikünNâsır Yûsuf'u metbû tanımaktaydılar. Bağdat'in 656'da (1258) Moğollar tarafından işgal edilmesiyle Eyyûbî hâkimiyetindeki Bilâdüşşam Moğol tehdidiyle karşı karşıya kaldı.

Moğollar’n Bilâdüşşam’ı işgali Eyyûbîler'in yıkılışı gibi önemli siyasî ve askerî sonuçlar doğurduğu kadar özellikle bölgenin merkezi olan Dımaşk'ta dinî, ilmî ve sosyal alanlarda birçok gelişmeye sebep oldu. Üç ana başlık altında ele alınabilecek olan bu gelişmeler ve işgalin sona

1 Eyyûbîler dönemi Dımaşk meliklerinin bir listesi için bk. Şeşen, Salahaddin'den Baybars'a Eyyûbîler, s. 272. 
ermesinin hemen ardından şehirde yaşananlar, sebepleri ve sonuçları itibariyle VII. (XIII.) asırda Dımaşk’taki dinî, ilmî ve sosyal yapıya ışık tutacak niteliktedir.

\section{Moğollar'ın Bilâdüşşam'ı İşgali ve Dımaşk Önlerine Gelişleri}

Eyyûbîler uzun süredir yaklaşmakta olan Moğol tehdidinin farkındaydılar. Moğollar’n doğudaki İslâm beldelerinde müslümanlara karşı giriştikleri katliam ve yağma haberleri bir süredir başta Dımaşk olmak üzere bütün Bilâdüşşam’da konuşulmakta ve yakından takip edilmekteydi. ${ }^{2}$ Nitekim Dımaşk Meliki en-Nâsır'ın Moğollar ile olan ilişkileri takip edilecek olursa onun daha Moğollar Bilâdüşşam’a gelmeden çok önce onlarla iyi ilişkiler kurma ihtiyacı hissettiği anlaşılmaktadır. O, 641 (1243) yılında Halep meliki olduğu dönemde ${ }^{3}$ Moğollar’a bir elçi göndermiş, 642'de (1244) onlara haraç ödemeyi kabul etmiş, 643'te (1246) ikinci bir elçilik heyeti görevlendirmişti. ${ }^{4}$ el-Melikü’n-Nâsır, 648'de ise (1251) Mengü’nün tahta çıkışını kutlamak üzere en yakınındaki isimlerden olan veziri Zeynüddin el-Hâfızîyi Moğollar’ın başşehri Karakurum’a göndermiş, bu ziyaret sırasında vezir Moğol hanından aldığı damga ve emanla Dımaşk’a dönmüştü. ${ }^{5}$ Bununla beraber takip eden yaklaşık on yıl boyunca Hülâgû bütün İran’ ele geçirirken el-Melikü’nNâsır’ın bu durum karşısında sessiz kaldığı görülmektedir. O, Moğollar’’n

2 Doğudaki olaylar özellikle buralardan Bilâdüşşam'a göç eden insanlar ve oralardan gelen haberler vasıtasıyla siyasî-askerî zümre tarafından dikkatle takip edilmekteydi. 616'da (1219) V. Haçlı Seferi sırasında Dimyat Haçlılar tarafından işgal edildiğginde Mısır Meliki el-Kâmil ve Dımaşk Meliki el-Muazzam, kardeşleri el-Cezîre Meliki el-Eşref'i Haçlılar'a karşı bir ittifak oluşturmaya davet ettiklerinde el-Melikü’lEşref doğudaki Moğol-Hârizmşahlar çatışması dolayısıyla idaresi altındaki toprakların Moğol tehdidi altında bulunduğunu ileri sürerek ittifaka katılmayı başlangıçta kabul etmemişti (bk. Humphreys, From Saladin to the Mongols, s. 167-68). Dönemin önde gelen âlimlerinden olan Yâkūt el-Hamevî de (ö. 626/1229) yıllar önce ilim tahsili için gittiği Horasan’ın Moğollar tarafından işgal edilmesi üzerine önce Irak'a, daha sonra Bilâdüşşam'a gitmişti (İbn Hallikân, Vefeyâtü̉l-a'yân, VII, 23; Sa'dî, Yâkūt el-Hamevî, s. 13). Dimaşk’ta bulunan Ebü'l-Yümn el-Kindî̀ye (ö. 613/1217) Horasan'da bulunan fakihlerin gönderdiği mektuplarda Hârizmşahlar ile Moğollar arasındaki mücadeleden bahsedilmekteydi (İbn Kesîr, el-Bidâye ve'nnihâye, XVII, 36).

el-Melikün-Nâsır Halep hükümdarı iken 648'de (1250) Memlükler'in Mısır'daki son Eyyûbî hükümdarı el-Melikü’l-Muazzam Turan Şah’ı öldürmesi üzerine Dımaşk’taki ümerâ tarafından şehre davet edilmiş ve Dımaşk’ı savaşmadan ele geçirmişti. Kısa sürede Hama dışındaki Bilâdüşşam’ın bütün şehirleri ya doğrudan onun topraklarına katılmış ya da ona tâbi olmuştu (Tomar, "el-Melikü’n-Nâsır Yûsuf", 78). 
bu girişimi karşısında herhangi bir tedbir girişiminde bulunmadığ ${ }_{1}$ gibi Hülâgû’ya hiçbir hediye ve kutlama göndermemiștir. ${ }^{6}$

Bütün bunlar el-Melikü’n-Nâsır’n neredeyse Bağdat işgal edilinceye kadar Moğol tehdidinin ciddiyetini anlayamamış olduğunu göstermektedir. Bağdat'in işgalinin ardından el-Melikün-Nâsır hemen bir elçilik heyetini hediyelerle birlikte Hülâgû̉ya göndererek iki taraf arasındaki iyi ilişkileri teyit etmek istedi. Elçiler Hülâgû̉nun yanında bulunan Şiî âlim Nasîrüddîn-i Tûsînin ${ }^{7}$ (ö. 672/1274) kaleminden çıktığı iddia edilen bir mektupla Dımaşk’a geri döndüler. Mektupta Abbâsî halifesinin yalancilığından ve Bağdat'ın nasıl ele geçirildiğinden bahsedilmekte ve el-Melikü’n-Nâsırdan Hülâgû̉nun tarafında mı yoksa onun karşısında mı yer aldığ 1 sorusuna cevap vermesi istenmekteydi. Ayrıca Hülâgû mektupta el-Melikü’n-Nâsır’ bizzat gelip biat etmeye çağırmaktaydı. ${ }^{8}$ el-Melikü’n-Nâsır Hülâgû̉nun gizli bir tehdit içeren mektubunu aldığında bu defa oğlu el-Melikü'l-Azîz Muhammed ve veziri Zeynüddin el-Hâfızîyi bir defa daha hediyelerle Hülâgû’ya gönderdi. Hülâgû yine el-Melikü’n-Nâsır'ın niçin bizzat gelmediğini sorduğunda elçiler Haçlı tehdidini gerekçe gösterdiler. ${ }^{9}$

Moğollar’ın Dımaşkı iş̧gali ve Eyyûbîler'in yıkılışı sürecinde el-MelikünNâsır’n veziri Zeynüddin el-Hâfızînin önemli rol oynadığı anlaşılmaktadır. el-Melikü’n-Nâsır ile Moğollar arasındaki ilişkilerde en önemli kişi olarak dikkati çeken Zeynüddin el-Hâfızî, el-Melikü’n-Nâsır tarafından defalarca Moğollar’a elçi olarak gönderilmiş, müzakerelerde bulunmuş ve Moğollar karşısında el-Melikü’n-Nâsır’n nasıl davranması gerektiği konusunda belirleyici isim olmuştur. Diğer taraftan her iki tarafın tarihini kaleme alan müellifler onun gizlice Moğollar'la iş birliği yaptığı konusunda hemfikirdirler. ${ }^{10}$ Onun

6 Humphreys, From Saladin to the Mongols, s. 339; Amitai-Preiss, Mongols and Mamluks, s. 21-22.

7 Agil Şirinov’a göre Hülâgû’nun Bağdat'i işgali sırasında ona Abbâsî Halifesi Müsta'sım-Billâh’ öldürmesini Nasîrüddîn-i Tûsînin tavsiye ettiği iddia edilse de konu hakkındaki kaynakların hiçbirinde bu husustan bahsedilmemektedir ("Tûsî, Nasîrüddin", s. 437).

8 Amitai-Preiss, Mongols and Mamluks, s. 22.

9 Ebü'l-Fidâ, Târîh, II, 205. el-Melikü’n-Nâsır'in bizzat huzuruna gelip itaat etmemesinden Hülâgû̀nun son derece rahatsız olduğu belirtilmektedir (Amitai-Preiss, Mongols and Mamluks, s. 23).

10 İlhanlı dönemi âlimi, tarihçisi ve devlet adamlarından Reşîüuddin Fazlullah, Zeynüddin el-Hâfızînin Hülâgû̉nun huzuruna son gelişinden çok daha önce kendilerine bağlllık arzettiğinden bahsetmektedir (Câmiu't-tevârîh, s. 52). Safedî de benzer şekilde Zeynüddin el-Hâfızînin Moğollar'la gizlice anlaştığını söyler. Ayrıca onu el-Melikü’nNâsır'ın Moğollar'a karşı çıkıp onlarla savaşmasını engellemekle, Moğollar'ın Bilâdüşşam’ı işgalini kolaylaştırmakla suçlar (el-Vâfî̀, XV, 253). 
Moğollar'la iş birliği içinde olduğu Dımaşk’’n işgali sırasında daha net şekilde ortaya çıkmıştır. Moğollar’ın Dımaşk üzerindeki baskısı arttı̆̆ında Kutuz'dan kaçarak el-Melikü’n-Nâsır’nn yanına gelen Bahrî Memlükleri emîrlerinden Baybars el-Bundukdârînin başını çektiği bir grup ümerâ Moğollar'la savaşılmasını isterken, Zeynüddin el-Hâfızî onlara karşı durulmamasını ve itaat edilmesini savunan hizbin en önemli temsilcisi olmuştur. ${ }^{11}$

el-Melikü’n-Nâsır’n elçilik heyetleri Hülâgû ile "anlaşma" yaparak Bilâdüşşam’ı Moğollar'dan korumaya çabalarken aslında Hülâgû'nun Bilâdüşşam üzerine yürüme kararını çok önceden verdiği anlaşılmaktadır. ${ }^{12}$ Nitekim Moğollar Bağdat’’n işgalinden kısa bir süre sonra Bilâdüşşam’a doğru harekete geçerek önce Meyyâfârikīn'i kuşattılar, ardından da Harran, el-Cezîre, Âmid, Urfa ve Nusaybin'i ele geçirdiler. Bir sonraki hedefleri ise Dımaşk'tan sonra Bilâdüşşam’ın en önemli şehri olan Halep oldu. ${ }^{13}$ Moğollar’n Bilâdüşşam’a yönelmelerinin ardından el-Melikü’n-Nâsır Moğollar'la ilişkilerini düzeltmek için son bir çaba daha sarfetti. Dönemin önde gelen isimlerinden İzzeddin İbn Şeddâd’’ (ö. 684/1285) Meyyâfârikīn’i kuşatmış olan Hülâgû̉nun oğlu Yeşmut'a gönderdi. Ancak bu girişiminden de herhangi bir netice alamad. ${ }^{14}$

657 (1259) yılı sonlarında Halep önlerine gelen Moğol kuvvetleri şehri kuşattılar. el-Melikü’n-Nâsır’n Halep nâibi el-Melikü’l-Muazzam Turan Şah şehre kapanıp savunma savaşı verilmesini emretti. ${ }^{15} 658$ (1260) yılı başların-

11 Zeynüddin el-Hâfızînin Moğollar'la iş birliği hakkında ayrıca bk. Humphreys, From Saladin to the Mongols, s. 340; Amitai-Preiss, Mongols and Mamluks, s. 23.

12

Bağdat'ın işgalinin ardından Mengüye kıymetli hediyelerle birlikte zaferini müjdeleyen bir mektup gönderen Hülâgû, mektubunda bir sonraki hedefinin Bilâdüşşam ve Mısır olacağını açıkça ifade etmiştir (Reşîdüddin Fazlullāh, Câmiu’t-tevârîh, s. 50).

Mogollar'ın Bağdat'tan Halep'e gidene kadar işgal ettikleri yerler için bk. Reşîdüddin Fazlullāh, Câmiu't-tevârîh, s. 53; Ebü'l-Fidâ, Târîh, II, 308; İbn Vâsıl, Müferricü'l-kürûb, s. 193. Müferricüll-kürûb'un 646-659 (1248-1261) yılları arasında meydana gelen olaylardan bahseden kısmı Mohamed Rahim tarafından Die Chronik des ibn Wasil. Ğamal ad-Din Muhammad ibn Wasil. Mufarrig al-Kurub fi Ahbar Bani Ayyub adıly neşredilmiş (Harrassowitz Verlag-Wiesbaden 2010), bu makalede de söz konusu neşir kullanılmıştır.

14 Avc1, “İbn Şeddâd, İzzeddin”, s. 375. İbn Şeddâd’ın bir amacı da Meyyâfârikīn kuşatmasını kaldırmaktı. Ancak o, bunu başaramadığı gibi Moğollar tarafından şehrin teslimi için aracılık etmek zorunda bırakılmıştır (Amitai-Preiss, Mongols and Mamluks, s. 23).

Halep’teki emîrlerin Moğollar karşısında nasıl bir strateji izleneceği konusunda kararsızlık yaşadığı anlaşılmaktadır. Şehirdeki askerler ilk başta Moğollar’a karşı saldırmak üzere şehirden çıktılarsa da düşmanın çok kalabalık olduğunu görünce şehre geri dönmüşlerdir. İbn Vâsıl, bu girişimden sonra Turan Şahı̉n şehirden çıkmayı yasakladığını ve şehre kapanıp savunma savaşı verilmesini emrettiğini belirtmektedir. Nitekim emri dinlemeyip şehirden çıkan asker ve halktan oluşan ikinci bir grubun tamamı Moğollar tarafından öldürülmüştür (İbn Vâsıl, Müferricüll-kürûb, s. 194-95). 
da Hülâgû Halep önlerine geldi ve kuşatma daha da şiddetlendi. Turan Şah'a elçiler göndererek şehrin teslimini talep eden Hülâgû, dönemin kaynaklar1na da yansıyan yazdığı mektupta ona şu teklifte bulundu:

Siz Moğollar’ın karşısına çıkmak için çok zayıfsınız. Bizim asıl hedefimiz ise el-Melikü’n-Nâsır ve askerleriyle savaşmak. Şimdi bizim, birisi şehirde diğeri de şehrin kalesinde olmak üzere iki şahne ${ }^{16}$ atamamızı kabul edin. Biz de el-Melikün-Nâsır’nn askerleri üzerine yürümeye devam edelim. Şayet müslümanlar karşısında zafer bizim olursa bütün şehirler gibi Halep de bizim elimize geçmiş olur, siz de müslüman kanının akmasını engellemiş olursunuz. Şayet savaşı biz kaybedersek ve müslümanlar zafer kazanırsa o vakit atadığımız şahneleri isterseniz serbest bırakırsınız isterseniz öldürürsünüz. ${ }^{17}$

Hülâgû̉nun teklifi Turan Şah tarafından reddedilince ${ }^{18}$ Moğollar Halep'e nihaî saldırıyı başlattılar. Halep güçlü surlarıyla müstahkem bir şehir olmasına rağmen kalabalık Moğol ordusu yoğun bir çatışmanın ardından 9 Safer 658 (25 Ocak 1260) tarihinde şehre girdi. ${ }^{19}$ Moğollar daha önce kendilerine karşı koyan bütün şehirlerde yaptıkları gibi Halep’te de büyük bir katliam ve yağma gerçekleştirdiler. Bu katliamdan sadece eman verilen birkaç ev ile bazı kilise ve hankahlara sığınanlar kurtulabildi. Beş gün boyunca devam eden kargaşanın ardından Hülâgû genel af ilân ederek şehirdeki yağmayı durdurdu. Müslümanların ibadetlerine devam etmesine, şehirde ezan okunup namaz kılınmasına izin verdi. Şehir düşmesine rağmen Moğollar’a direnmeye devam eden kaledeki birlikler de kısa süre sonra teslim oldu. ${ }^{20}$

16 Bir şehir veya bölgenin emniyet ve asayişinden sorumlu askerî vali (geniş bilgi için bk. Merçil, "Şahne”, s. 292-93).

17 Farklı kaynaklarda yer alan mektubun içeriği büyük ölçüde aynıdır (İbn Vâsıl, Müferricüll-kürûb, s. 196; Ebü'l-Fidâ, Târîh, II, 310; İbn Kesîr, el-Bidâye ve’n-nihâye, XVII, 396).

18 İbn Vâsıl, Müferricü̈l-kürûb, s. 196; Ebü'l-Fidâ, Târîh, II, 310. Şehirde bulunanların Hülâgû̉nun teklifini reddetmelerinin önemli bir sebebi de şüphesiz Moğollar’n daha önce İslâm şehirlerinde eman vermiş olsun veya olmasın halka uyguladıkları katliam ve zulümlerdi. Nitekim Reşîdüddin Fazlullah onların Bağdat'ı işgalleri sırasında teslim olan şehirde uyguladıkları katliam ve yağmalardan bahsetmektedir (Câmiu't-tevârîh, s. 44-47).

19 Hülâgû Halep’e saldırı emrini verince Moğol askerleri önce şehrin etrafına bir hendek kazmış ve kazdıkları bu hendeğin önüne bir duvar örmüşlerdir. Ardından da duvarın hemen arkasına çok sayıda mancınık getirerek şehir surlarını bu mancınıklarla dövmeye başlamışlardır. Diğer taraftan ise duvarın hemen arkasından şehrin surlarına lağımlar kazarak surları yıkmaya, şehre tüneller açmaya girişmişlerdir (İbn Vâsıl, Müferricü'l-kürûb, s. 197).

20 İbn Vâsıl, Müferricü'l-kürûb, s. 197; Ebü'l-Fidâ, Târîh, II, 310; Reşîüdin Fazlullah şehrin bir hafta boyunca yağmalandığını, kaledeki direnişin ise kırk gün sürdüğünü belirtmektedir (Câmiu't-tevârîh, s. 54). Ayrıca kalenin düşmesinin ardından ilerleyen 
Hülâgû Halep’i ele geçirdikten sonra el-Melikü’n-Nâsır döneminde hapse atılan dokuz Bahrî Memlükleri emîrini serbest bırakarak himayesine almıştır. ${ }^{21}$ Hülâgû̉nun bu davranışı onun ele geçirdiği bölgelerdeki yerel elitleri ve muhalif güçleri kendi tarafına çekme siyasetinin bir parçası olarak değerlendirilebilir. ${ }^{22} \mathrm{O}$, Bilâdüşşam’a gittiğinde yerel askerî ve sivil güçleri devşirmeye önem vermiştir. Hülâgû’nun Halep’te serbest bıraktığ 1 emîrleri önce Bilâdüşşam ve Mısır’n işgalinde kullanmayı, ardında da buraların elde tutulmasında onlardan yararlanmayı düşünmüş olması muhtemeldir.

Halep’in düşmesiyle birlikte Bilâdüşşam'daki özellikle yerel askerî ve siyasî güçlerin hızla pozisyonlarını belirlemeye çalıştıkları dikkati çekmektedir. Moğollar’n önündeki en büyük engellerden biri olarak görünen Halep’te yaşananların Bilâdüşşam’nn diğer şehirlerinde büyük bir korku ve endişeye sebep olduğu anlaşılmaktadır. Humus Meliki el-Melikü’l-Eşref, Halep kuşatması sırasında Dımaşk Meliki el-Melikü’n-Nâsır ile birlikteyken şehrin düşmesinin ardından onun yanından ayrılarak Halep’e Hülâgû̉nun huzuruna gitmiş ve ona bağlıllğıını bildirmiştir. Hülâgû tarafından çok iyi karşılanan el-Melikü’lEşref'in Humus üzerindeki hâkimiyeti tanınmış, ${ }^{23}$ ayrıca o Hülâgû tarafından Bilâdüşşam genel valisi olarak atanmıştır. Fakat tamamen göstermelik olan bu atama aslında yine Hülâgû̉nun ele geçirdiği yerlerin kontrolü için yerel liderlerden yararlanma siyasetinin bir parçası olarak değerlendirilmelidir. Zira bu bölgelerde güç ve kontrol Moğollar’ın elinde kalmaya devam etmiştir.

Hama Meliki el-Meliküll-Mansûr ise şehri kaderine terkederek yakın ailesi ve maiyetiyle Mısır'daki Memlükler'e sığınmıştır. el-Melikü'l-Mansûr'un şehirden ayrılmasından sonra Hama'daki âyan büyük bir korku ve tedirginlikle şehrin anahtarlarını Hülâgûya teslim etmek ve ondan eman istemek için Halep'e gitmiştir. Hama halkının talepleri kabul edilmiş ve Hülâgû̉nun vali atamasının ardından şehir Moğollar’ın hâkimiyetine geçmiştir. Buna rağmen Hama, Moğol yağma ve zulmünden kurtulamamıştır. ${ }^{24}$

dönemde muhtemel bir isyan vb. harekete müstahkem bir sığınak olmaması için şehrin surları ve kalesi Moğollar tarafından tahrip edilmiştir (İbn Vâsıl, Müferricüllkürûb, s. 201).

21 Bu emîrlerin isimleri için bk. Makrîzî, Kitâbüss-Sülûk, I/1-2, s. 422-23.

22 Hülâgû yerel askerî güçleri kendi ordusunun bir parçası haline getirme siyasetini Bağdat'ın işgali sırasında da uygulamıştır. Kuşatma sırasında yanına gelen Bağdat'ın önde gelen iki emîrine eman ve hediyeler vererek onları maiyetindekileri de beraberlerinde getirmeleri için şehre geri göndermiştir. Reşîudüdün Fazlullah’a göre Hülâgû bu askerleri Bilâdüşşam ve Mısır üzerine gerçekleştireceği seferlerde kullanmak istemiștir (Câmiu't-tevârîh, s. 44).

23 İbn Vâsıl, Müferricü̉l-kürûb, s. 200-201; ayrıca bk. Ebû Şâme, Terâcim, s. 206.

24 İbn Vâsıl, bütün bunların yanında Moğollar’ın ele geçirdikleri bütün şehirlerin kalelerini ve surlarını tahrip ettiklerini, fakat Haçlı bölgelerine yakın ve buradan 
Dımaşkin işgaline geçmeden önce, bu noktada son olarak Bilâdüşşam’ın diğer şehirlerinin de Dımaşk’tan önce veya sonra Moğollar tarafından işgal edildiğini belirtmek gerekir. Bu şehirlerden olan Ba'lebek, yerel elitten birinin $^{25}$ ve Moğollar’n hapisten çıkararak kendi taraflarına çektiği bir başka yerel emîrin gayretleriyle Moğol katliam ve yağmalarından kurtuldu. Ba'lebek'in eski valilerinden olan Bedreddin Yûsuf el-Hârizmî, Ba'lebek'in ardından başka birçok bölgede valilik görevi üstlenmiş birisiydi. Daha sonra el-Melikü’n-Nâsır Yûsuf tarafından Dımaşk’ta hapse atılmış, Moğollar’ın şehre gelişine kadar hapis hayatı yaşamıştı. Moğollar tarafından serbest bırakılan Hârizmî, Hülâgû̉nun yanına giderek onu Ba'lebek'i kolaylıkla itaat altına alabileceğine inandırdı ve Hülâgû tarafından Ba'lebek'e vali olarak atandı. Halk tarafından eskiden de sevilen biri olan Hârizmî, Ba'lebek’e gider gitmez kale dışında şehirde düzeni kolayca sağladı. İlerleyen zamanda kale Moğollar tarafından ele geçirilip yağmalansa da Hârizmî şehirdeki halkın can ve mal güvenliğinin korunmasında önemli rol oynadı. ${ }^{26}$

Ba'lebek'in ardından Kudüs, Nablus, Aclûn, el-Halîl, Askalân gibi şehirler de Moğollar tarafından ele geçirildi ve yağmalandı. Bilâdüşşam'daki en önemli şehir olan Dımaşk’ın Moğollar tarafından ele geçirilmesi ise şehirdeki yaklaşık yüzyıllık Eyyûbî hâkimiyetini sona erdirdi.

\section{Dımaşk'ın İşgali ve Şehirde Yaşananlar}

Moğollar'in Halep’i ele geçirmesi, burada gerçekleştirdikleri yağma ve katliamlar, ümerâ ve halktan çok sayıda müslümanın yaşadıkları şehirleri terketmeleri gibi gelişmeler Dımaşk’ta yakından takip edilmekteydi. Dımaşkı̉n önde gelen fakihlerinden Ebû Şâme el-Makdisî de 658 (1260) yılı

gelebilecek bir tehdide açık olduğu için Hama Kalesi'ne dokunmadıklarını belirtmektedir (Müferricül-kürûb, s. 198, 201).

25 Takıyyüddin el-Hadîsî el-Haşâişî adındaki aslen Ba'lebekli olan bu kimse ilk öğreniminin ardından Mısır'a gitmiş, burada botanik ve tıp alanında dersler almış ve bu alanda döneminin önde gelen isimleri arasına girmiştir. Önce Memlük Sultanı elMelikü'l-İzzeddin Muîz Aybek'in himayesine girmiş, onun tarafından Dımaşk’a elMelikü’n-Nâsır Yûsuf'a gönderildiği sırada Aybek'in öldürülmesi üzerine Dımaşk’ta kalmıştır. Daha sonra Hülâgû, el-Melikü’n-Nâsır'dan aralarında Takıyyüddin'in de bulunduğu bir grup âlimi yanına göndermesini isteyince Hülâgû̉nun yanına gitmiş ve kendisine büyük itibar gösterilmiştir. Hülâgû Bilâdüşşam’ı işgale girișince onun yanına giderek Ba'lebek için eman içeren bir ferman ve şehrin şahneliğini istemiş, bu isteği kabul edilmiştir. Bunun üzerine Ba'lebek’e giderek akrabalarının da aralarında bulunduğu halka Moğollar'a itaat etmelerini tavsiye etmiştir (Yûnînî, Zeylü Mirâti'zzamân, I, 352-53).

26 Yûnînî, Zeylü Mirâti'z-zamân, I, 353-55. 
girdiğinde şehirde Moğollar'la ilgili haberlerin oldukça arttığından bahsetmektedir. ${ }^{27}$ Bununla beraber özellikle ümerâ arasında korku ve endișe ile şehirlerini terkedip kaçanlar, bahsi geçtiği üzere, sadece Hama ve Humus melikleri değildi. Bu isimlerin başında Bilâdüşşam'daki en önemli Eyyûbî meliki olan el-Melikün-Nâsır Yûsuf bulunmaktaydı.

el-Melikün-Nâsır Halep kuşatma altındayken Dımaşk yakınlarındaki Berze'de bulunan karargâhındaydı. Beraberinde Mısır'da başa geçen Kutuz'dan kaçarak yanına gelen Memlükler'in önde gelen emîrlerinden Baybars el-Bundukdârî de bulunmaktaydı. Fakat bir süre sonra kendisine yönelik Baybars’n adının da karıştığı bir suikast hazırlığı iddiaları ortaya atılınca elMelikü’n-Nâsır Dımaşk'a döndü. Baybars ise Gazze'ye, daha sonra da yeniden anlaştığı Kutuz’un yanına Mısır’a gitti. ${ }^{28}$ Halep’in düştüğü haberi Dımaşk’a ulaşınca el-Melikü’n-Nâsır korkuyla Dımaşk’ı terkederek Filistin’e kaçtı. Nablus yakınlarına geldiğinde yanında Hama ve Humus melikleri de bulunmaktaydı. el-Melikü’n-Nâsır burada Mısır’a elçi göndererek Memlükler'le anlaşmanın yollarını aradı, ancak beraberindeki emîrler arasında yaşanan anlaşmazlık sonucu onları terkedip Katya’ya gitti. Bunun üzerine Hama Meliki elMansûr Mısır'a giderek Memlükler'e sığındı. el-Melikü’n-Nâsır ise Filistin'de bir süre daha kaldıktan sonra emîrlerinden birinin ihaneti sonucu Moğollar tarafından yakalandı ve Hülâgû̉nun yanına Tebriz’e gönderildi. ${ }^{29}$

el-Melikü’n-Nâsır’n Dımaşk'tan kaçmasının şehirdeki halkın Moğollar'a karşı hissettiği korkuyu ve tedirginliği daha da arttırdığı anlaşılmaktadır. Bu sırada birçok kimse Dımaşk’ terkederek başta Mısır olmak üzere yakınlardaki bölge ve şehirlere göç etti. Bu durum şehirde ihtiyaç maddelerinin fiyatlarında büyük artışa sebep oldu. ${ }^{30}$ Göç edenlerin çoğu kış şartlarında düştükleri yollarda soğuktan öldü, birçoğu ise yağma ve talana mâruz kald. ${ }^{31}$ Diğer taraftan şehirden ayrılanlar sadece müslümanlar değildi. Bu sırada hıristiyanlardan da birçok kimse Moğollar'dan kaçarak Haçlı işgalindeki şehirlerden biri olan Sur’a sığındı. ${ }^{32}$

27 Terâcim, s. 203.

28 İbn Vâs1, Müferricüll-kürûb, s. 194-96.

29 el-Melikü’n-Nâsır Yûsuf yakalanıp Hülâgû̉nun yanına gönderilince Hülâgû, önce kendisine topraklarının geri verileceğini vaat etmiş, fakat müslümanların Aynicâlût Savaşı'nda Moğollar’ı büyük bir yenilgiye uğratması üzerine el-Melikü’n-Nâsır ve beraberindekilerin idam edilmesini emretmiştir (İbn Vâsıl, Müferricüll-kürûb, s. 2oo, 205; Yûnînî, Zeylü Mirâti'z-zamân, I, 350; Ebü'l-Fidâ, Târîh, II, 311; Tomar, “el-Melikü’nNâsır Yûsuf", 78).

30 Özellikle yolculuk için en büyük ihtiyaç olan binek hayvanı fiyatlarında büyük artış olduğundan bahsedilmektedir (Makrîzî, Kitâbü’s-Sülûk, I/1-2, s. 423).

31 Ebû Şâme, Terâcim, s. 203; ayrıca bk. İbn Vâs1l, Müferricül-kürûb, s. 194.

32 Humphreys, From Saladin to the Mongols, s. 351. 
Bu şartlar altında Moğollar’a karşı koyacak askerlerin çoğu el-Melikü’nNâsır ile beraber Dımaşk'tan ayrıldığ i için âyan ve eşraf şehri savaşmadan teslim etmeye karar verdi. ${ }^{33}$ Şehrin önlerine gelen Moğol elçileri 17 Safer 658 (2 Şubat 1260) tarihinde Dımaşk’a girdiler. Ertesi gün öğlen namazının ardından Emeviyye Camii’nde Hülâgû̉nun fermanı okundu. Yaklaşık bir ay kadar sonra da Hülâgû̉nun Dımaşk’a atadığı nâibi Ketboğa Noyan ve Moğol askerleri şehre girdi ve şehrin önde gelenleri tarafından merasimle karşılandılar. Ardından da el-Meydânülahdar'da Dımaşk ve çevresinde yaşayanlara eman verildiğine dair ikinci bir ferman daha okundu. ${ }^{34}$ Dımaşk Kalesi’ndeki az sayıdaki askerin direnişi de kısa bir süre sonra kırıldı. Ardından Moğollar ele geçirdikleri şehirlerde yaptıkları gibi Dımaşk Kalesi ve şehir surlarını tahrip ettiler. ${ }^{35}$

Moğol askerlerinin Dımaşk'a girişiyle hemen hemen aynı zamanda Bilâdüşşam’ın yakın gelecekteki siyasî ve askerî durumunu önemli ölçüde etkileyecek bir olay meydana geldi. Hülâgû Halep’te bulunduğu sırada Moğol Büyük Hanı Mengü öldü ve Moğollar taht kavgalarılla mücadele etmek zorunda kaldı. Hülâgû onun ölüm haberini alınca taht mücadelelerini yakından takip edebilmek için doğudaki topraklarına çekilirken ordusunun büyük bir bölümünü de beraberinde götürdü. Geride ise yerine Bilâdüşşam’ın işgalini tamamlaması ve yeni yerler ele geçirmesi için Dımaşk’a gönderdiği kumandanı Ketboğàyı bıraktı. ${ }^{36}$

Moğollar Dımaşk'ı ele geçirdikten sonra katliam ve yağmaya girişmediler. Fakat şehirde bulunanlar yine de müslümanların uğradıkları zulümlere

33 Reşîüddin Fazlullah, Dımaşk’taki önde gelenlerin şehrin tesliminden önce çeşitli hediyeler ve şehrin anahtarlarıyla Hülâgû’nun huzuruna gelerek ondan eman istediklerini, Hülâgû'nun da onlara acıyarak şehre eman verdiğini belirtmektedir (Câmiu'ttevârîh, s. 54). Nüveyrî̀nin anlatımına göre, şehrin savaşmadan Moğollar’a tesliminde o sırada el-Melikü’n-Nâsır'ın Dımaşk'ta bulunan veziri Zeynüddin el-Hâfızî önemli rol oynamıştır (Nihâyetü'l-ereb, XXVII, 263).

34 Ebû Şâme, Terâcim, s. 203; Yûnînî, Zeylü Mirâtitz-zamân, I, 349.

35 Ebû Şâme, Terâcim, s. 204; İbn Vâs1l, Müferricül-kürûb, s. 202; Yûnînî, Zeylü Mirâtìzzamân, I, 351-52.

36 Reşîdüddin Fazlullāh, Câmiu't-tevârîh, s. 55; Humphreys, From Saladin to the Mongols, s. 356; Jackson, The Mongols, s. 116. Hülâgû ordusunun büyük bir bölümünü beraberinde götürmüş ve geride daha mütevazi bir askerî güç bırakmıştır. Nüveyrîye göre Hülâgû’nun Bilâdüşşam'da nispeten zayıf bir askerî güç bırakmakla yetinmesinde Dımaşk Meliki en-Nâsır Yûsuf'un Hülâgû'ya anlattıklarının etkisi olmuştur. Hülâgû, yakalandıktan sonra yanına getirilen el-Melikün-Nâsır'a, Mısır'daki Memlükler ve onların askerî güçleri hakkında sorular sormuş, el-Melikü’n-Nâsır cevabında Mısır'da az sayıda asker bulunduğunu ve az bir güçle onları yenebileceğini söylemiştir. Bunun üzerine Hülâgû Bilâdüşşam’da Ketboğa kumandasında küçük bir birlik bırakarak doğuya gitmiştir (Nihâyetül-ereb, XXVII, 263). 
şahitlik etmek zorunda kalmıştır. Moğol askerleri Dımaşk’ta kontrolü sağladıktan sonra Filistin’e yönelerek Kudüs, Belkā, Kerek gibi şehirleri işgal edip buralarda büyük yağma ve katliamlar gerçekleştirmiş, çok sayıda müslümanı da esir almışlardı. Bu esirlerin çoğu Dımaşk ve Halep gibi şehirlerin çarşı ve pazarlarında satılmış, bazıları ise doğudaki Moğol şehirlerine götürülmüşșür. ${ }^{37}$

Moğollar'ın gerek insanlar arasında saldıkları dehşet gerekse hâkimiyetlerini pekiştirme kaygısıyla attıkları bazı adımlar Dımaşk’ın idarî, ilmî ve sosyal hayatını yakından ilgilendiren neticeler doğurmuştur. Hâkimiyetlerinin özellikle Dımaşk ulemâsı ve ilmî hayatına nasıl etki ettiği ve müslüman-gayrimüslim ilişkilerinde ne türden dönüşümlere sebep olduğu gibi meseleler işgal sırasında yaşananlara ışık tutacak niteliktedir.

\section{a. İşgal Döneminde Dımaşk’taki Hıristiyanlar}

Dımaşk’ın işgali müslümanlarla şehirdeki hıristiyanlar arasındaki ilişkilerde önemli gerilimler yaratmıştır. Bu gerilimin temelinde işgalle birlikte hıristiyanların müslümanlara karşı giriştikleri birtakım olumsuz davranışlar yatmaktadır.

Ketboğảnın Dımaşk’a girmesinin ardından şehirdeki hıristiyanlar Hülâgû̀ya çeşitli hediyelerle birlikte bir heyet göndermiş, bu heyet hıristiyanlara bazı yeni haklar tanıyan bir fermanla Dımaşk'a dönmüştü. Daha sonra bazı hıristiyanlar alenen kendi dinlerini öven, İslâm’a ise hakaret eden sözler söylemeye başlamış, mescitlerin kapılarında durarak hem namazdan çıkan müslümanların üzerine hem de bazı mescitlerin ve hankahların kapılarına şarap dökmüşlerdi. Bu sırada ellerinde taşıdıkları büyük bir haçla çarşıda yürüyüş yapmış, karşılarına çıkan bütün müslümanları bu haç karşısında ayağa kalkmaya zorlamış, kalkmayanların ise dükkânlarını ateşe vermişlerdi. Dahası müslüman esnafa türlü eziyetlerde bulunmuşlar, alenen İslâm’a hakaret eden konuşmalar yapmışlardı. Bütün bu taşkınlıklar karşısında müslümanlar şehrin Moğol nâibine şikâyette bulunmak üzere kaleye gittiklerinde nâip onları dinlemediği gibi yanındaki hıristiyan papazları müslümanlardan üstün tutmuş ve onlara hakaret ederek kaleden kovmuştu. Ayrıca Moğol nâibinin sürekli şehirdeki kiliseleri ziyaret etmesi hıristiyanları daha da cesaretlendirmişti. Ebû Şâme Moğollar’nn sebep olduğu tedirginlik henüz ortadan kalkmamışken, gerek Moğol nâibinin gerekse ondan destek bulan hıristiyanların

37 Ebû Şâme, Terâcim, s. 204; İbn Vâsıl, Müferricü’l-kürûb, s. 201; Yûnînî, Zeylü Mirâti’zzamân, I, 351 . 
tavırlarının müslümanlarda rahatsızlık meydana getirdiğini ve onları daha büyük bir endişeye sevkettiğini belirtmektedir. ${ }^{38}$

$\mathrm{Bu}$ noktada temel sorulardan biri Moğollar’’n gelişinin müslümanlarla hırıstiyanlar arasındaki ilişkiyi niçin olumsuz yönde etkilediğidir. Bazı araştırmacılar bu sorunun cevabını "Cengiz yasaları" ile ilişkilendirirler. Moğollar’nn temel hayat düsturlarını oluşturan, "Cengiz yasaları" arasında yer alan iki maddenin onların hâkimiyetleri altındaki dinî gruplarla aralarındaki ilişkiyi büyük ölçüde şekillendirdiği kabul edilmektedir. ${ }^{39} \mathrm{Bu}$ maddelere göre Moğollar ele geçirdikleri bölgelerdeki halklar üzerinde herhangi bir dinî baskı kurmamakta, onları belirli bir dinî kabule zorlamamakta ve hâkimiyetleri altındaki dinî zümreleri vergiden muaf tutmaktaydılar. Onların yönetimleri altındaki her dinî zümre birbirine eşitti ve aynı haklara sahipti. Nitekim buradan hareketle Moğollar’n Dımaşk'ta yaptıklarının dinî bir özgürlük alanı oluşturmak olduğunu, hıristiyanların bu durumu sevinç gösterileriyle karşıladıklarını, müslümanların ise yaşananlara aşırı tepkiler verdiklerini dile getiren yaklaşımlar ortaya atılmıştır. ${ }^{40}$

Hıristiyanların işgal sırasında yaptıklarına bakıldığında Moğollar’n şehirdeki hıristiyanların konumunda önemli bir değişim yarattıkları ortadadır. Zira Moğollar gelmeden önce Eyyûbî idaresinde Dımaşk'ta yaşayan hıristiyanlar zimmî statüsündeydiler. Cizye ödemekte, ${ }^{41}$ İslâm hukukunun kendilerine tanıdığı haklar ölçüsünde şehirde yaşamaya devam etmekteydiler.

38 Ebû Şâme, Terâcim, s. 208; şehirdeki hıristiyanların yaptıklarıyla ilgili ayrıca bk. Yûnînî, Zeylü Mirâtizz-zamân, I, 362-63; Makrî̀î, Kitâbü's-Sülûk, I/1-2, s. 398. Hülâgû’nun Bilâdüşşam'da yerine bıraktığı kumandanı Ketboğa da hıristiyanlarla yakın ilişki içerisinde olmuştur. Hatta bazı araştırmacılar tarafından onun hıristiyan olduğu iddia edilmektedir (Bk. Lane, Early Mongol Rule, s. 12).

39 Spuler, İran Moğolları, s. 22o. Söz konusu iki maddeden birinde, “Tanrı’nın hoşuna gitmek için birer araç olduklarından bütün dinlere eşit olarak saygı gösterilmelidir”, diğerinde ise "Ebû Tâlib'in oğlu Ali’nin bütün ardından gelenleri, bütün fakirler, Kur'an okuyucular, fakihler, hekimler, bilginler, rakîbler, inzivada yaşayanlar, müezzinler ve ölü yıkayıcılar vergi ve resimlerden muaftır" denilmektedir (Alinge, Moğol Kanunları, s. 143-44). Diğer taraftan bu hükümler değerlendirilirken "Cengiz yasaları" olarak bilinen hükümlerin nihaî bir formla Cengiz’e ait olduğu düşünülmemeli, çeşitli Moğol devlet ve hükümdarları tarafından yeniden düzenlenip tatbik edildiği dikkate alınmalidir (Kafalı, “Cengiz Han”, s. 369).

40 Peter Jackson'a göre Moğollar’nn Dımaşk’ta yaptıkları aslında Cengiz yasalarına uygun davranmaktan başka bir şey değildir. Ona göre Hülâgû̉nun Bilâdüşşam’daki nâibi Ketboğa, hıristiyanlara özel bir muamelede bulunmamış, onlara özel bir sempati göstermemiştir (The Mongols, s. 120). Amitai-Preiss ise yaşananlarla ilgili değerlendirmelerinde müslümanların hıristiyanlarla eşit sayılmayı hazmedemediklerini iddia etmektedir (Mongols and Mamluks, s. 46).

41 Eyyûbîler dönemi cizye uygulamaları hakkında bk. Alshech, "Islamic Law, Practice and Legal Doctrine”, s. 363-74; Kuşçu, Eyyûbî Devleti Teşkilatı, s. 301-303. 
İlişkilerdeki sınırları belirleyen ise temelde İslâm hukukuydu ve Moğollar’n gelişi şehirdeki mevcut yapıyı değiştirdi.

$\mathrm{Bu}$ anlatılanlarla irtibatlı olarak, "Moğollar’n yaptıkları sadece müslümanlarla hıristiyanlar arasında eşit bir statü kurmak mı, yoksa -belki bunun yanında- işgal ettikleri bölgelerde uyguladıkları yerel işbirlikçi gruplar edinme siyasetinin bir uzantısı mıdı? Ya da müslümanların tepkisi sadece hıristiyanlarla artık eşit muamele görecek olmalarından mı kaynaklanmaktaydı?" gibi sorular cevaplanmayı beklemektedir. Hıristiyanların söz konusu davranışları sergilemelerinin arkasındaki saikin ne olduğu bu sorulara verilecek cevaplarla yakından ilişkilidir.

Moğol tarihçisi Bertold Spuler, Moğollar’n hıristiyanlarla özel bir ilişki geliştirdikleri görüşündedir. Ona göre Hülâgû zamanında Moğollar müslüman coğrafyada kendilerine bağlı bir zümre elde edebilmek için hıristiyanları desteklemişlerdi. Hıristiyanlar ise Moğollar’ı yıllardır süren müslüman tahakkümünden kurtulmak ve doğudan gelen bu gücü hıristiyanlaştırarak kendi taraflarına çekmek için bir firsat olarak görmüşlerdi. ${ }^{42}$ Nitekim Hülâgû̉nun hıristiyanlarla olan ilişkileri hem kendinden önceki hem de kendi dönemindeki diğer Moğol hükümdarlarına göre daha sıkı ve ileri seviyedeydi. Hülâgû̉nun eşi Dokuz Hatun Nestûrî bir hıristiyandı ve kumandanları arasında da çok sayıda hıristiyan bulunmaktaydı. Hülâgû müslüman coğrafyayı işgal ederken özellikle yerel hıristiyan krallardan ve halktan destek görmüştü. Bu süreçte Gürcü ve Ermeni hıristiyanlar Moğollar’’n batı s1nırının korunmasında önemli rol oynadılar. Kilikya Ermeni Kralı Hetum, Hülâgû batıya yöneldiğinde ona ilk bağlllık arzeden hükümdarlar arasında yer almıştı. ${ }^{43}$

$\mathrm{Bu}$ durumla irtibatlı olarak Ketboğa’nın Dımaşk'a beraberinde Ermeni Kralı Hetum ve aynı zamanda Hetum'un damadı olan Antakya Haçlı Kontu VI. Bohemund ile birlikte girmesi Moğollar’n şehirdeki yerli hıristiyanlara vermek istedikleri bir mesaj olarak değerlendirilebilir. Dımaşk'taki yerel yöneticilerin hıristiyanlarla olan yakın ilişkileri, onların kiliselerine sürekli yaptıkları ziyaretler ${ }^{44}$ ve şehirdeki çoğunluğu teşkil eden müslümanların hassasiyet ve şikâyetlerinin dikkate alınmaması gibi hususlar Moğollar’ın şehirdeki hıristiyanlarla özel bir ilişki biçimi geliştirmeye çalıştıklarına işaret etmektedir.

42 İran Moğolları, s. 262.

43 Lane, Early Mongol Rule, s. 38.

44 İbn Kesîr, el-Bidâye ve'n-nihâye, XVII, 398. 
Son olarak Kudüs ve çevresindeki Haçlılar'ın Moğollar’a karşı bir tavır takınmaları Moğollar ile hıristiyan gruplar arasındaki ilişkilerin değerlendirilmesi açısından dikkate değerdir. Nitekim Aynicâlût Savaşı̉nda bazı Haçlı birlikleri müslümanlarla aynı safta Moğollar’a karşı savaşmak istemiştir. ${ }^{45}$ Bütün bunlar Moğollar ile hıristiyanlar arasındaki ilişkinin salt müslümanlara karşı bir ittifak ilişsisi olmaktan ziyade karşılıklı bir menfaat ilişkisi olduğuna işaret etmektedir.

\section{b. İşgal Döneminde Ulemâ}

Moğol işgali öncesinde Dımaşk’ta başta medreselerdekiler olmak üzere ulemâya tahsis edilen çok sayıda mansıp vardı. Eyyûbî ailesi mensupları, emîrler, âlimler ve varlıklı kimseler tarafından şehirde birçok medrese inşa edilmişti. ${ }^{46}$ Medreseler ulemâ için müderrisliğin yanı sıra, mütevellilik, nâzırlık, muitlik gibi çeşitli mansıpları bünyesinde barındırmaktaydı. Aynı şekilde Zengîler ve Eyyûbîler döneminde ihdas edilen sûfî vakıflarından sorumlu şeyhüşşüyûhluk ${ }^{47}$ ile aynı zamanda bürokratik bir görev olan beytülmal vekilliği gibi Dımaşk ulemâsının getirildiği başka mansıplar da bulunmaktaydı. Bütün mansıplar arasında şüphesiz en önemlisi kādılkudatlık idi. Adlî, ilmî, idarî pek çok alanda söz sahibi olan kādılkudat, sadece D1maşk’taki değil, çoğu zaman bütün Bilâdüşşam’daki ilmî mansıplar üzerinde söz sahibiydi. Medreselerdeki mansıplara atamalar çoğu zaman şehirdeki kādılkudat tarafından yapılmakta, aynı şekilde atanan kimseler yine onun tarafından görevden alınabilmekteydi. ${ }^{48}$ Bu açıdan kādılkudat, ulemânın getirildiği mansiplar üzerinde melikten sonra söz sahibi en önemli kişi durumundayd.

45 Moğollar ile savaşmak için Mısır'dan ayrılan Memlük ordusu Haçlılar'in elinde bulunan Akkâ yakınlarına geldiğinde şehirdeki Haçlı şövalyeleri müslümanlarla birlikte Moğollar'a karşı savaşmak istediklerini belirterek Sultan Kutuz ile görüşmüşlerdi. Sultan onlara teşekkür edip güzel muamelede bulunmuş, ancak bu isteklerini reddetmiş, bununla beraber savaş sırasında tarafsız kalmaları hususunda onlarla anlaşmıştı (Makrîzî̀, Kitâbü’s-Sülûk, I/1-2, s. 430; ayrıca bk. Lane, Early Mongol Rule, s. 39; Jackson, The Mongols, s. 117).

46 Eyyûbîler tarafından Dımaşk'ta kurulan medreseler için bk. Yılmaz, "Zengîler ve Eyyûbîler Döneminde Dımaşk’ta Medrese”, s. 48-88.

47 Şeyhüşşüyûhluk hakkında ayrıntılı bilgi için bk. Yılmaz, "Meşîhatüşşüyûh"un Doğuşu", s. 1-21.

48 Bu dönemde medrese müderrisleri medrese vâkıfları tarafından da atanabilirdi. Lâkin her halükârda müderrisliğin önce kādılkudat sonra da melik tarafından onaylanması gerekmekteydi (bu dönemdeki müderris atama ve azilleri hakkında bk. Yılmaz, “Zengîler ve Eyyûbîler Döneminde Dimaşk’ta Medrese”, s. 126-32). 
Diğer taraftan kimin tarafından kurulmuş olursa olsun melikler medreselerdeki mansıplar üzerinde mutlak kontrole sahiplerdi. İslâm toplumunun en önemli unsuru olan ulemânın himayesi, şehirdeki hayatın dinî, idarî, sosyal ve daha pek çok açıdan sağlıklı yürümesi için son derece önemliydi. Mansipları kontrol ediyor olmak onlara ulemânın doğrudan ya da dolaylı desteğini sağladığından bu durum meliklerin hem şehirdeki hâkimiyetleri açısından hem de sosyal, dinî ve ilmî hayatın düzenli işleyişi açısından vazgeçilmezdi. Ulemâ ise mansıplar sayesinde hem hayatlarını idame ettirmek için maddî zorluklarla mücadele etmek zorunda kalmamakta hem de ilmî pratiklerini daha rahat icra edebilecekleri bir ortama kavuşmuş olmaktaydı. Sağladığı avantajlar dolayısıyla mansıplar gittikçe artacak şekilde ulemânın ilgisini çekmiş, bu durum zamanla ulemâ arasında mansıp mücadelelerinin daha sık yaşanmasını beraberinde getirmiştir.

Bütün bunların yanında ulemâ -her ne kadar sınırları kesin olarak belirlenmemiş ve niteliği şartlara göre değişkenlik gösteriyor olsa da- Dımaşk'ta bağımsız ve otonom bir konuma sahipti. Medresede mansip sahibi olmak netice itibariyle ilmî hayatını sürdürebilme açısından tek yol değildi ve eskiden olduğu gibi şehirde hiçbir mansıp sahibi olmaksızın ilmî faaliyetlerini sürdüren çok sayıda âlim vardı. Diğer taraftan her melik idaresi altındaki şehirlerde ulemânın himayesine büyük önem vermekteydi. Önde gelen bir âlimin kendi şehirlerinde dersler vermesi, müderrislik veya kadılık gibi bir mansıba sahip olması melikler açısından hem halk hem de diğer melikler karşısında bir itibar vesilesiydi. Diğer yandan melikler idareleri altındaki bölgelerde dinî ve sosyal hayatın düzenli işleyişi açısından da ulemâya ihtiyaç duymaktaydılar. Dolayısıyla farklı himaye kaynaklarının mevcudiyeti ulemânın melikler karşısındaki konumunu güçlendirmekte, onlara daha özgür bir alan açmaktaydı. Öyle ki melikler arasındaki siyasî mücadeleler, hatta şehrin melikler arasında el değiştirmesi gibi olaylar ulemânın şehirdeki konumunu ve sahibi oldukları mansıplarla ilişkilerini çoğu zaman etkilememekteydi. Bu durumun genellikle tek istisnası kādılkudatlıkta yaşanmaktaydı. İlmî mansıplar ve dolayısıyla ulemâ üzerinde büyük etkisi olan kādılkudat şehrin yeni hâkimleri tarafından hâkimiyetlerinin tahkimi için değiştirilebilmekteydi.

Moğollar da Dımaşk’a geldiklerinde şehirdeki hayatı kontrol altına almak için ulemâ ile iş birliği yapmaya çalıştılar. Bu sebeple ilk yaptıkları işlerden biri şehirdeki kādılkudatı değiştirmek oldu. Ketboğảnın Dımaşk’a girmesinin hemen ardından Hülâgû’nun Kemâleddin Ömer b. Bündâr et-Tiflisîyi (ö. 672/1273) Bilâdüşşam'daki bütün şehirlerin yanı sıra Mardin, Meyyâfârikīn 
ve Musul kadısı olarak atadığına dair ferman Dımaşk'a ulaştı. Ayrıca buralardaki bütün vakıfların idaresi de Tiflisîye verildi. ${ }^{49}$

Ömer et-Tiflisî şehrin önde gelen fakihlerinden ve kadılıkta son derece tecrübeli bir kimseydi. Moğollar şehre gelmeden önceki on beş yıl boyunca kadılık görevini yürüten Sadreddin İbn Seniyyüddevle’nin (ö. 658/1260) iki nâibinden birisi olarak görev yapmıştı. Bununla beraber Tiflisînin kādılkudatlığı çok kısa sürdü. Kaynakların onun kādılkudatlığı döneminden bahsederken vurgu yaptıkları az sayıdaki husustan biri yetkisi olmasına rağmen görevi sırasında başka hiçbir mansıp edinmemesidir. ${ }^{50}$ Böyle bir vurgu öncelikle Moğollar’n meydana getirdiği çalkantı ve değişimin bir kādılkudatın şehirdeki nüfuz alanını genişletebileceği müsait bir zemin doğurmuş olmasıyla ilgilidir. Fakat en az bu durum kadar sonraki dönemde yaşanan ve ulemâ tarafından tepkiyle karşılanan bazı gelişmelerin de Tiflisî hakkında düşülen bu kayıtta etkisi vardır.

Yaklaşı iki ay görev yaptıktan sonra azledilen Tiflisînin yerine Hülâgû tarafından Muhyiddin Yahyâ İbnü'z-Zekî (ö. 668/1269) atand.. ${ }^{51}$ Onun kādılkudatlığa getirilişi Dımaşk ulemâsının şehirdeki siyasî hâkimiyetin değişmesi karşısında kendi konumlarını nasıl muhafaza ettiğinin bir göstergesidir. İbnü'z-Zekî ve Tiflisîden önceki kādılkudat Sadreddin İbn Seniyyüddevle Dımaşk Moğollar tarafından işgal edilir edilmez aileleriyle birlikte Halep’e Hülâgû̉nun yanına gitmiş ve ona bağlılıklarını sunmuşlardı. İkisi de kādılkudat olarak atanmayı beklemekteydi. Fakat İbn Seniyyüddevle'den daha atik ve girişken olan İbnü’z-Zekî Hülâgû̀nun gözüne girmeyi başardı ve bütün Bilâdüşşam’ın kādılkudatı olarak atandı.

Bununla beraber Hülâgû’nun İbnü’z-Zekîyi sadece huzuruna kadar gelen girişken bir âlim olduğu için kādılkudatllğa getirdiğini düşünmek her şeyden önce Moğollar’nn siyasî tecrübelerini küçümsemek anlamına gelir. Hülâgû̉nun bu kararı verirken İbnüz-Zekînnin başka özelliklerini de dikkate aldığında şüphe yoktur. Öncelikle Hülâgû, onu bu göreve getirerek kādılkudatllğa en az Ömer et-Tiflisî kadar önemli bir ismi geçirmiş oldu. Diğer yandan ise Muhyiddin İbnü'z-Zekî, Dımaşk’’n ilmî ve sosyal hayatında

49 Ebû Şâme, Terâcim, s. 204; Yûnînî, Zeylü Mirâti’z-zamân, I, 350.

50 İbnü’l-İmâd, onun geniş bir aileye sahip fakir bir kimse olmasına rağmen kadılığ 1 sırasında kendisi için hiçbir menfaat sağlamadığını, hiçbir şey edinmediğini ve hiçbir medreseyi de kendisine tahsis etmediğini belirtmektedir (Şezerâtü'z-zeheb, VII, 589; ayrıca bk. Safedî, el-Vâfî, XXII, 273).

51 Ömer et-Tiflisî, Dımaşk’taki görevinden ayrıldıktan sonra Halep’e gitti ve Moğollar tarafından Halep kadılığına getirildi (Sübkî, Tabakât, VIII, 309-310; İbnü’l-İmâd, Şezerâtü'z-zeheb, VII, 589). 
önemli bir yere sahip şehirdeki en önemli Şâfiî ailelerden olan Benî Kureşîye mensuptu. Şehrin yerli ulemâ ailelerinden olan Benî Kureşî, Tuğteginliler, ${ }^{52}$ Zengîler ve Eyyûbîler döneminde çok sayıda âlim yetiştirmiş, mensupları medreselerde müderrislikler edinmiş, çeşitli şehirlerde kadılıklar ve kadı nâipliği yapmış, defalarca Dımaşk kādılkudatlığına getirilmiş bir aile idi. Muhyiddin İbnü'z-Zekînnin babası ve dedesi de dahil olmak üzere kendisinden önceki dört nesil Dımaşk'ta kādılkudatılı yapmış, aile ise toplamda altı kādılkudat çıkarmıştı. ${ }^{53}$ Hülâgû, Muhyiddin İbnü’z-Zekî̀yi kādılkudat olarak atarken onun sahip olduğu tecrübenin yanında kendisi ve ailesinin şehirdeki nüfuzundan da yararlanmak istemişti.

İbnüz-Zekînin kādılkudatllğga atanışı sırasında gerçekleştirilen merasim kaynaklarda detaylı bir şekilde yer almaktadır. Buna dair anlatılanlar ulemânın yeni oluşan şartlar karşısında kendi pozisyonunu belirlemede ne kadar hızlı davrandığını göstermesi bakımından önemlidir. Hülâgû̉nun yanından ayrılan İbnü’z-Zekî ve İbn Seniyyüddevle ilk olarak Ba'lebek'e geldi. Ertesi günü İbnü’z-Zekî, etrafında hizmetçileri, çocukları ve maiyetiyle Emîniyye Medresesinde cuma namazını kıldı. Daha sonra burada kādılkudatlığa atandığına dair taklit okundu. İbnü’z-Zekînin kardeşi Şehâbeddin İsmâil b. Eśad’ın ise kadı nâibi olarak atandığı ilân edildi. Taklitte kendisinden büyük övgülerle bahsedilen İbnü’z-Zekî, merasim sırasında üzerinde oldukça süslü bir hil'at giymişti. ${ }^{54}$ Ba'lebek’teki merasimden sonra İbnü’z-Zekî Dımaşk’a gitmek için yola çıkarken İbn Seniyyüddevle rahatsızlanarak Ba'lebek'te kaldı ve kısa bir süre sonra da burada vefat etti. ${ }^{55}$ İbnü'zZekî Dımaşk’a gittiğinde şehirde ikinci ve daha büyük bir merasim icra edildi. Emeviyye Camii’nde kādılkudat olarak atandığına dair taklit okundu. $\mathrm{Bu}$ sırada Hülâgû̉nun adı her geçtiğinde merasimde hazır bulunanların başlarından altınlar ve gümüşler saçıldığı, merasime Moğollar’n şehirdeki nâibi ve eşinin de katıldığ belirtilmektedir. ${ }^{56}$

İbnü'z-Zekînin göreve başladıktan kısa bir süre sonra şehirdeki mansıplar üzerinde kendi hâkimiyetini kurmaya çalıştı̆̆ı dikkati çekmektedir.

52 Zengîler'den önce 1104-1154 yılları arasında Dımaşk merkez olmak üzere bu yöredeki bazı şehirlerde hüküm süren bir Türk-İslâm hanedanı (geniş bilgi için bk. Bezer, "Tuğteginliler", 349-51).

53 Benî Kureşî ailesi kādılkudatları için bk. Gilbert, "The Ulama of Medieval Damascus”, S. 158.

54 Yûnînî, bu hil'atin Abbâsî halifesi tarafından en-Nâsır Yûsuf'a gönderilen hil'at olduğunu, Halep işgal edildiğinde Hülâgû̉nun eline geçtiğini ve onun tarafından İbnü’zZekîye verildiğini belirtmektedir (Yûnînî, Zeylü Mirâti’z-zamân, I, 356).

55 Yûnînî, Zeylü Mirâti'z-zamân, I, 356; Zehebî, Târihu'l-İslâm: 651-66o, s. 334.

56 Yûnînî, Zeylü Mirâti'z-zamân, I, 357; İbn Kesîr, el-Bidâye ve’n-nihâye, XVII, 403. 
Yeni kādılkudat ilk olarak Sâlihiyye ve Şûmâniyye gibi medreselerin müderrislerini değiştirerek buralara başkalarını atadı. Ayrıca elinde bulundurduğu Azîziyye ve Takaviyye medreselerine ek olarak Azrâviyye, Sultâniyye, Felekiyye, Rükniyye, Kaymeriyye ve Kellâse medreselerinin müderrisliğini de kendi uhdesine aldı. Emîniyye Medresesinni ise oğlu Îsầya verdi. Kendi nâibi olarak atadığı kardeşi Şehâbeddin İsmâil’e ise, her ne kadar vâkıfları müderrislerinin birden fazla medresede görev yapmalarını yasaklamış olsa da, Revâhiyye ve Şâmiyye Berrâniyye medreselerini verdi. Oğlu Îsâyı ayrıca şeyhüşşüyûh olarak atadı. ${ }^{57}$

Ebû Şâme el-Makdisî, Moğollar Dımaşk'a vardıktan sonra şehrin önde gelenlerinin yönetimde onlarla birlikte hareket etmeye başladıklarını söyler. ${ }^{58}$ Ömer et-Tiflisî, Sadreddin b. Seniyyüddevle ve Muhyiddin İbnü’z-Zekî ulemâ arasında bu durumun en dikkat çekici isimleridir. Her üç isim de Eyyûbî hâkimiyeti boyunca meliklerle yakın ilişki içerisinde olmuş, medreselerde müderrislikler yapmış, kadılık görevlerine getirilmiş, çok sayıda talebe yetiştirmiş ve Dımaşkı̉n en önemli fakihleri arasında yer almışlardır. Bu noktada onların değişen şartlara uyum sağlamada bu kadar hızlı davranıyor gözükmelerinin sebebi ve bunun pratik sonuçları sorgulanmalıdır.

Şüphesiz bu durumun sebeplerinden birisi İbnü’z-Zekî örneğinin açık şekilde gösterdiği üzere ulemânın şehrin özellikle ilmî hayatında güçlü bir yer edinme ve otoritesini tahkim etme isteğiydi. Medreselerin ulemâ açısından ne anlama geldiğine daha önce değinilmişti. Bu sebeple özellikle kadılık, şeyhüşşüûhluk ve medreselerdeki mansıplar üzerinde ulemâ arasında mücadeleler yaşanabilmekteydi. Moğollar’ın gelişi ve şehirde yeni bir düzen kurulma ihtimalinin ortaya çıkışı bazı âlimleri kendi konumlarını garantiye almaya, hatta bu durumu yeni mansıplar edinebilmek için bir fırsat olarak görmeye sevketmiş olmalıdır.

Diğer taraftan başka birçok İslâm şehri gibi Dımaşk da Moğol işgaliyle İslâm fetihlerinden sonra ilk defa müslüman olmayan bir gücün tahakkümü altına girmiştir. Bu durum müslümanları daha önce pek de alışı olmadıkları yeni problemlerle yüz yüze bırakmıştır. ${ }^{59}$ Nitekim şehri ele geçiren yeni

57 Ebû Şâme, Terâcim, s. 206; Yûnînî, Zeylü Mirâti’z-zamân, I, 357.

mesi neticesinde bu toprakların İslâm hukuku açısından konumu ve bu bölgelerde yaşayan müslümanların nasıl hareket etmeleri gerektiği gibi meselelerin yoğun şekilde tartışılmaya başlandığı dönemler esas olarak VI-VIII. (XII-XIV.) asırlardır. Bu dönemin en belirgin özelliği İslâm coğrafyasının gayrimüslim bir unsur olan Moğollar tarafından işgal edilmiş olmasıdır. İslâm beldelerinin karşılaştığı bu yeni durum özellikle söz konusu dönemlerden itibaren âlimlerin eserlerinde konu edinilmiş, fetva 
hâkimler müslüman olmasalar da şehirdeki halk müslümandı ve şehirdeki hayatın sağlıklı bir şekilde devam etmesi gerekmekteydi. Şehirdeki hayatın düzenli işleyişi müslüman nüfus açısından son derece önemliydi ve ulemâ yıllardır olduğu gibi bu konuda en kritik konumdaki gruptu. Ayrıca bu durum sadece müslümanları ilgilendiren bir mesele değildi. En az şehirdeki müslümanlar kadar Moğol idareciler de şehirdeki hayatın sorunsuz bir şekilde işleyişini istemekteydiler. Bu durum onların özellikle siyasî ve ekonomik kaygıları açısından gerekliydi. Onlar da kendileriyle müslüman halk arasındaki iletişimi sağlayacak ve topluma bütün dinamikleriyle sağlıklı bir işleyiş kazandıracak grup olarak ulemâya muhtaçlardı. Zira ulemâ İslâm toplum hayatının her alanında doğrudan yer alan ve ona yön veren figürlerdi. Onlar toplumun genel işleyişini tayin eden, İslâm’ın hükümlerine işlerlik kazandıran, onu pratiğe döken, denetleyen ve yeri geldiğinde hükümlerini ihlâl edenleri cezalandıran, bu kurallara uymayan fiilleri, davranışları ve kişileri ise meşruiyet dairesinin dışına çıkarabilen yegâne kimselerdi. Ulemânın bu rolü onların toplum üzerinde sahip oldukları büyük nüfuzun kaynağıydı. ${ }^{60}$

İşte Moğollar’ın bu beklentileri Dımaşk’ta en azından bir grup ulemâ tarafından memnuniyetle karşılanmış görünmektedir. Ayrıca ulemânın Moğol idarecilere olan yakınlığının şehirde müslümanlar açısından bazı olumsuzlukların yaşanmasını engellemiş olabileceği de unutulmamalıdır. Meselâ Ömer et-Tiflisînin Moğollar tarafından büyük saygı duyulan ve sözü dinlenen bir kimse olduğu, ayrıca onun Dımaşk'ta müslüman kanının dökülmesine engel olan en önemli kimselerin başında geldiği kaynaklarda sıkça vurgulanmaktadır. $^{61}$

\section{c. Ulemâ Göçü}

Moğollar'ın Halep’te gerçekleştirdikleri katliam ve yağma haberi Dımaşk'a ulaşınca birçok insanın şehri terkederek başka bölgelere kaçtıklarına değinilmişti. Moğollar Dımaşk'a girdiklerinde şehirde bulunan fakih Ebû Şâme elMakdisî, bu süreçte yalnızca Allahın kalplerine ve imanlarına kuvvet verdiği insanların şehirde kaldıklarını söylerken şehri terkedenlere gizliden gizliye

kitaplarında tartışılır olmuş ve canlı bir tartışma alanına dönüşmüştür (İslâm tarihinde bu meseleyi konu edinen ilk çalışmalar için bk. Özel, "Klasik İslâm Devletler Hukukunda Ülke Kavramı", s. 43-42).

6o Dımaşk’ta ulemânın siyasî ve sosyal hayatta oynadığı meşrulaştırıcı rol hakkında detaylı bilgi için bk. Yılmaz, "Zengîler ve Eyyûbîler Döneminde Dımaşk'ta Medrese", s. 222-35.

61 Safedî, el-Vâfî, XXII, 273; İbnü'l-İmâd, Şezerâtüz-zeheb, VII, 589. 
sitem eder. ${ }^{62}$ Onun bu ifadeleri bir açıdan Moğol döneminde şehirde kalan, hatta Moğol hâkimiyetinde bazı görevler üstlenen ulemânın gerçekte büyük bir cesaret ve fedakârlık gösterdiğine işaret olarak değerlendirilebileceği gibi diğer yandan şehri terkeden insanların çokluğunu da göstermektedir.

Neyi kastettiği bir kenara zikri geçen sitemiyle Ebû Şâme, aslında İslâm tarihi boyunca ulemâ için en önemli kaygılardan biri olan ilmî çalışmalar için güvenli ortam ihtiyacını görmezden gelmiştir. Nitekim VI ve VII. (XII ve XIII.) asırlarda siyasî istikrarsızlık ve güvenlik sorunun ortaya çıktığı bölgelerdeki ulemâ, bulundukları şehri terketme kararını sıradan insanlara göre daha kolay verebilmekteydi. Bu dönemde ulemâ daha güvenli gördükleri yerlere giderek buralarda kolayca başka mansıplar edinebileceklerini düşünmekteydiler. Özellikle âlimler, şairler ve tabipler gittikleri her yerde melikler, emîrler ve halk tarafından el üstünde tutulmaktaydılar. Nitekim bu dönemde Dımaşk ulemâsının çoğunluğunu çeşitli sebeplerle doğup büyüdükleri yerleri terketmiş ve ilmî hayatını Dımaşk'ta sürdürmeyi seçmiş âlimler oluşturmaktaydı. Dolayısıyla ulemâ açısından asıl olan ilmî faaliyetlerini rahatlıkla sürdürebileceği bir ortam bulabilmekti. ${ }^{63}$ Nitekim Moğol tehdidiyle yüzleşen Dımaşk’ta şehri terkedenler sadece halktan insanlar değildi. Bu kimseler arasında çok sayıda fakih, devlet görevlisi, şair, tabip gibi çeşitli zümrelerden kimseler de bulunmaktaydı.

Dımaşk’ı terkeden önde gelen isimlerden ikisi Kemâleddin Ebü'l-Fezâil Abdüllatîf (ö. 659/1261) ve Takıyyüddin b. Rezîn el-Hamevî (ö. 680/1281) idi. Önemli bir Hanefî fakihi olan Kemâleddin Abdüllatîf Dımaşk'ta yıllardan beri Belhiyye, Hatuniyye Cevvâniyye ve Zencâriyye medreselerinin müderrisliğini yürütmekteydi. Moğollar’ın Halep’i ele geçirip Dımaşk’a yönelmeleri üzerine şehirden kaçtı. Geride bıraktığı medreselerinin müderrisliğine ise başkaları getirildi. Fakat Moğollar şehirden ayrıldıktan sonra Dımaşk’a geri döndü ve medreselerdeki mansıplarını yeniden elde etti. ${ }^{64}$

Dımaşk'tan kaçarak Mısır'a giden Takıyyüddin b. Rezîn ise daha Dımaşk’ta iken şehrin ilmî ve dinî hayatında kendisine seçkin bir yer edinmiş önemli bir Şâfiî fakihi idi. Küçük yaşından itibaren ilim tahsil etmiş, döneminin

62 Terâcim, s. 203.

63 VI-VII. (XII-XIII.) asırlarda Dımaşk ulemâsının şehre hangi bölgelerden geldikleri ve siyasî istikrarsızlıkların ulemâ üzerindeki etkisi hakkında bir değerlendirme için bk. Yılmaz, "Zengîler ve Eyyûbîler Döneminde Dımaşk'ta Medrese”, s. 132-42.

64 Nuaymî, ed-Dâris, I, 482, 511, 527. Kemâleddin Abdüllatîf daha sonra Baybars tarafından Moğollar üzerine gönderilen Abbâsî halifesinin başında bulunduğu sefere katılmış, fakat Fellûce yakınlarında Moğollar tarafından öldürülmüştür (sefer hakkında ayrıntılı bilgi için bk. Ebû Şâme, Terâcim, s. 213-14; İbn Kesîr, el-Bidâye ve’n-nihâye, XIII, 272). 
önde gelen hocalarından dersler almış, başta fikıh ve tefsir olmak üzere hilâf, hadis, mantık gibi ilimlerde söz sahibi olmuştu. Otuzlu yaşlarında geldiği Dımaşk'ta beytülmal vekilliği ve Şâmiyye Berrâniyye Medresesi müderrisliği gibi görevlere getirilmişti. Moğol tehdidinden kaçıp Mısır’a gidince burada kısa sürede ilmî faaliyetlerini sürdürebileceği yeni imkânlar edindi. Mısır'da çok sayıda medresede müderrislik yaptı ve ilerleyen yıllarda Kahire kadılığına kadar yükseldi. ${ }^{65}$

Fakihlerin yanında özellikle tabiplerden de Mısır’a kaçanlar vardı. Bunlardan biri olan Osman b. Yûsuf b. Haydara er-Rahbî (ö. 688/1260) tıp eğitimini babasından ve dönemindeki önemli tabiplerden almıştı. Doğma büyüme Dımaşklı idi ve Nûriyye Bîmâristanı’nda görev yapmaktaydı. Ticaretle uğraştığından özellikle Mısır’a çok sık seyahat ederdi. Muhtemelen bu durumun da etkisiyle Moğollar Dımaşk’a yönelince iyi bildiği Mısır’a göç etti ve kısa bir süre sonra burada vefat etti. ${ }^{66}$ Diğer bir tabip Muvaffakuddin Abdüsselâm ise meşhur tabip Mühezzebüddin ed-Dahvâr'in öğrencilerindendi ve Halep günlerinden beri el-Melikü’n-Nâsır Yûsuf'un özel tabipliğini yapmaktaydı. Moğollar’ın gelişiyle o da Misır'a gitti. ${ }^{67}$

Mısır'a gidenler arasında çeşitli devlet görevlileri ve âyandan isimler de vardı. Bu kimseler arasında yer alan Nâsırüddin Muhammed b. Gālib b. Muhammed Dımaşk divanlarında görev yapmakta olan bir kâtip idi. ${ }^{68}$ Fahreddin b. İsmâil b. Ali ise önceleri Dımaşk'ta kâtiplik yapmış edip bir kimseydi. Daha sonra el-Melikün-Nâsır Yûsuf'un yanındaki şairler arasında yer aldı. O da Moğollar’’n gelişiyle Mısır'a göç etti. ${ }^{69}$ Edip ve özellikle ensab ilminde bilgili bir Şiî âlim olan Muhlisüddin el-Mübârek b. Yahyâ el-Hımsî ise Cebelilübnan taraflarına kaçanlar arasındaydı. ${ }^{70}$ Dımaşk’’n önde gelenleri arasında yer alan Cemâleddin Yûsuf ed-Debâbîsî ve Şerefeddin İbnü'l-İz gibi bazı isimler ise gittikleri Mısır'da çok kısa bir süre sonra vefat ettiler. ${ }^{71}$ Onlarla benzer şekilde şehrin önemli ailelerinden olan Benî Asâkire mensup

65 Safedî, el-Vâfî, III, 15-16; İbn Kādî Şühbe, Tabakāt, II, 147-49.

66 İbn Ebû Usaybia, Uyûnül-enbâ', s. 682.

67 Muvaffakuddin Abdüsselâm Mısır'da bir süre kaldıktan sonra Hama’ya giderek burada Hama Meliki el-Melikü'l-Mansûr'un özel tabipliğini üstlendi (İbn Ebû Usaybia, Uyûnü'l-enbâ', s. 755-57; Safedî, el-Vâfî, XVIII, 266-67).

68 Safedî, el-Vâfî, IV, 220.

69 Fahreddin b. İsmâil Mısır'a gittikten sonra burada eski hayatını terkederek züht hayatı yaşamaya başlamış, Moğollar çekildikten sonra tekrar Dımaşk’a dönmüş ve burada özellikle İbnü’l-Arabînin eserleriyle ilgilenmiş, insanlar tarafından büyük saygı duyulan bir kimse olmuştur (Safedî, el-Vâfî, IX, 99).

70 Yûnînî, Zeylü Mirâtíz-zamân, I, 385.

71 Ebû Şâme, Terâcim, s. 205. 
Ebû Hâmid el-İmâd el-Hüseyin de Dımaşk'tan kaçtıktan bir süre sonra vefat haberi şehre ulaşanlardandı. O, Dımaşk’’n Moğol işgalinden kurtulduğu haberini alınca beraberindekilerle Dımşak'a dönmek için yola çımış, fakat yolda vefat etmişti. ${ }^{72}$

\section{Dımaşk'tan Çekiliş ve Nizamın Yeniden Tesisi}

25 Ramazan 658'de (3 Eylül 1260) Bilâdüşşam’daki Moğol kuvvetlerinin Memlükler tarafından Aynicâlût'ta yenilgiye uğratılması yaklaşık bir yıldır devam eden bölgedeki Moğol hâkimiyetini sona erdirdi. ${ }^{73}$ Savaşın ardından aralarında Dımaşk’’n da bulunduğu Bilâdüşşam’daki şehirler hızla Memlükler' in eline geçti. Dımaşk yaklaşı sekiz ay boyunca Moğol işgalinde kalmıştı. ${ }^{74}$ Memlükler'in zafer haberinin Dımaşk’a ulaşmasıyla birlikte şehirde Moğollar’n izlerinin her alanda hızla silindiği yeni bir sürecin başladığ 1 anlaşılmaktadır.

Aynicâlût'taki zafer haberi Dımaşk'a ulaşınca ilk olarak şehirdeki Moğol idarecileri, askerleri ve Zeynüddin el-Hâfızî gibi yerel işbirlikçilerden kaçabilenler şehri hızla terkettiler. Fakat bunların çoğu daha sonra yakalanarak ya esir edildiler ya da öldürüldüler. Kutuz'un zaferi müjdeleyen mektubunun Dımaşk'a ulaşmasının hemen ardından müslümanlar ayaklanarak Mogollar ile iş birliği yapanlara karşı saldırılara giriştiler. Özellikle hıristiyanların Moğol hâkimiyeti sırasında takındıkları tavır müslümanlarda büyük bir rahatsızlık uyandırmıştı. Birkaç gün devam eden kargaşa döneminde

72 Ebû Şâme, Terâcim, s. 209.

73 Aynicâlût Savaşı Moğollar’n ilk defa mağlûp oldukları ve batıya doğru ilerleyişlerinin durduğu savaş olarak bilinir. Mısır'da hâkim olan Memlükler, İslâm dünyasında Moğolların önündeki son askerî ve siyasî güç durumundaydı. Ayrıca Bilâdüşşam ve Irak’ta Moğollar’ın önünden kaçan pek çok askerî grup da Memlükler’e sığınmıştı. Savaştan kısa bir süre önce Emîr Kutuz, bazı emîrlerin ve ulemânın desteğiyle Moğol kuvvetlerine karşı koyabilecek durumda olmadığı iddiasıyla küçük yaştaki Sultan el-Melikü’l-Mansûr Alìyi azlederek el-Melikü'l-Muzaffer lakabıyla kendisi Memlük tahtına oturmuştu. Mısır’n teslimini talep eden Moğol elçileri Kahire’ye ulaştıklarında Kutuz emîrleriyle yaptığg istişareler sonucu Moğollar ile savaşmaya karar vermiş, elçileri de öldürtmüştü. Bütün müslümanları Moğollar’a karşı girişilecek cihada çağıran Kutuz kumandasındaki Memlük ordusu Filistin'deki Aynicâlût mevkiinde Hülâgû̉nun Bilâdüşşam’daki nâibi Ketboğa Noyan kumandasındaki Moğol ordusunu kesin bir yenilgiye uğratmıştır. Savaşın kazanılmasında Kutuz’un şahsî gayret ve liderliği ile kumandanlarından Baybars el-Bundukdârî önemli rol oynamıştır (Aynicâlût Savaşı hakkında detaylı bilgi için bk. Reşîdüddin Fazlullāh, Câmiu't-tevârîh, s. 56-57; Makrîzî, Kitâbü’s-Sülûk, I/1-2, s. 427-32; Özaydın, "Aynicâlût Savaş1", s. 275-76; AmitaiPreiss, Mongols and Mamluks, s. 26-49).

Makrî̀î, Kitâbü’s-Sülûk, I/1-2, s. 432. 
hıristiyanlara ait çok sayıda ev ve dükkân yakıldı, şehirdeki bazı kiliseler tahrip edildi. Bu sırada yahudilere karşı da bazı yağma olayları yaşandıysa da bu kısa bir süre sonra sonlandırıldı. ${ }^{75}$

Kutuz zaferden yaklaşık beş gün sonra 30 Ramazan'da (8 Eylül) halkın büyük sevgi ve sevinç gösterileri içinde Dımaşk’a girdi. İlk olarak şehirdeki işleri düzene koyması için Sencer el-Halebîyi vali tayin etti. Ardından hıristiyanlara yönelik yağma ve saldırıları durdurarak kargaşayı sona erdirdi. ${ }^{76}$ Daha sonra Moğollar ile birlikte hareket eden şehirdeki bazı kimseler ve emîrler onun emriyle idam edildi. Bu isimlerden birçoğu Moğollar'n hapisten çıkarıp kendilerine mansıp verdiği emîrlerdi. Bu kimselerden olan ve Moğollar’n Bîre'yi ele geçirdiklerinde hapisten kurtarıp kendisine Banyas ve Subeybe kalelerini verdikleri Hasan b. el-Melikü'l-Azîz b. İmâdüddin, Aynicâulût'ta müslümanlar tarafından yakalandıktan sonra Dımaşk'ta Kutuz tarafından idam edildi. ${ }^{77}$ Fahreddin Muhammed b. Yûsuf el-Gencî gibi iş birliği ile suçlanan bazı kimseler ise şehirde ayaklanan halk tarafından öldürüldüler. Dımaşk'tan ayrılanların mallarına el koyanlar arasında yer aldığı iddia edilen Gencî, Emeviyye Camiỉnde halkın saldırısına uğrayarak öldürüldü. ${ }^{78}$ Şehirde Moğollar ile iş birliği yaptıkları için öldürülen başka kimseler de vardı. ${ }^{79}$

Daha önce Moğol tehdidi dolayısıyla Dımaşk’ı terketmiş olanların bazıları Moğollar gittikten sonra şehre geri döndüler. Bu durum her ne kadar işgal ve kargaşa sebebiyle zarar görmüş olan şehrin ekonomisine olumsuz etki yapsa $\mathrm{da}^{80}$ şehirdeki hayatın eskiye dönüşü açısından son derece önemliydi.

75 Bunda yahudilerin işgal sırasında müslümanlara karşı hıristiyanlar gibi davranmamaları etkili olmuştur (şehirdeki müslüman halkın ayaklanması sırasında meydana gelenler hakkında bk. Ebû Şâme, Terâcim, s. 208; Yûnînî, Zeylü Mirâti'z-zamân, I, 362-63).

76 İbn Vâsıl, Müferricül-kürûb, s. 216. Dımaşk'ta bunlar meydana gelirken Halep’te de benzer şeyler yaşanmaktaydı. Şehir Aynicâlût'ta kazanılan zaferin hemen ardından Memlükler'in kontrolüne geçmişti. Kutuz Dımaşk’a vali atadığı sırada Halep’e de vali olarak Musul hâkimi Bedreddin Lü’lü’ün oğlu Alâeddin’i atadı. O Moğollar’a biat etmeyerek Mısır'a kaçmış, Aynicâlût Savaşı’nda da Kutuz'un ordusunda savaşmıştı (Amitai-Preiss, Mongols and Mamluks, s. 46).

77 Ebû Şâme, Terâcim, s. 207; Yûnînî, Zeylü Mirâti'z-zamân, I, 361, 367.

78 Diğer taraftan kaynaklar Gencîden ilim sahibi bir kimse olarak bahsetmektedir. Ancak Ebû Şâme ve Yûnûnî onun Râfızî olduğunu iddia etmektedirler (Terâcim, s. 208; Zeylü Mirâti'z-zamân, I,362-63).

79 Bu kimseler için bk. Yûnînî, Zeylü Mirâti’z-zamân, I, 362.

80 Şehri terkedenlerin geri dönmesiyle birlikte şehirde özellikle temel ihtiyaç malzemelerinin çoğu tükendiğinden fiyatlar fahiş derecede yükselmiştir (Makrîzî, Kitâbüs'sSülûk, I/1-2, s. 434). Aynı dönemde Dımaşk ekonomisini olumsuz yönde etkileyen ve şehirde fiyatların yükselmesine sebep olan bir diğer olay Haçlılar tarafından basılan ve Yafiyye olarak isimlendirilen değeri düşük dirhemlerin tedavüle girmesi olmuştur (Ebû Şâme, Terâcim, s. 211). 
Daha önce geçtiği üzere Kemâleddin Abdüllatîf gibi ulemâdan isimler şehre döndüklerinde daha önceki mansıplarını yeniden elde ettiler. Bununla beraber yeni durumdan esas etkilenen ulemâ grubunun ișgal döneminde önemli mansıplara getirilenler olduğu dikkati çekmektedir. Nitekim Memlükler'in şehre hâkim olmasıyla birlikte ulemânın getirildiği mansıpların çoğu bir defa daha el değiştirmiştir.

Moğollar özellikle kādılkudatlıkta ve bu yolla medreselerdeki mansıpların dağıtımında önemli değişiklikler yapmışlardı. Moğollar’ın Dımaşk’taki ilk kādılkudatı Ömer et-Tiflisî daha sonra Moğollar tarafından Halep kadılığına getirilmişti. Tiflisî kādılkudatlığın yanında zaman zaman Ketboğảnın elçiliğini de yapmıştı. ${ }^{81}$ Halep yeniden müslümanların hâkimiyetine girdiğinde şehirde bulunan Tiflisî82 ${ }^{82}$ urada kendisine karşı oluşan tepkilere dayanamayarak şehri terketti ve Misır’a gitti.

Mevcut Dımaşk Kādılkudatı İbnü’z-Zekî ise geride kalan dönemde elde ettiği ve yakınlarına dağıttığı mansıpları muhafaza edebilmek için büyük çaba sarfettiyse de bunu yaklaşık bir ay başarabildi. Kutuz Dımaşk’a geldikten kısa bir süre sonra onu kādılkudatlıktan azlederek Mısır’a gönderdi. Elinde tuttuğu diğer mansiplar da kendisinden alındı. Kādılkudatlığa ise Necmeddin İbn Seniyyüddevle getirildi. ${ }^{83}$

Necmeddin İbn Seniyyüddevle, Dımaşk’ın önde gelen ulemâ ailelerinden olan Benî Seniyyüddevle'nin hayattaki en önemli temsilcisiydi. O, aynı zamanda Eyyûbîler'in son dönemlerinde şehirde yıllarca kādılkudatlık yapan ve Moğollar Dımaşk’̉ ele geçirdiğinde kādılkudatlık beklentisiyle Hülâgû̉nun huzuruna giden Sadreddin İbn Seniyyüddevle’nin de oğluydu. Döneminin önde gelen isimlerinden eğitim alarak yetişmiş önemli bir Şâfiî fakihi idi. Daha önceleri babasının kādılkudatlığı sırasında onun nâiplerinden biri olarak görev yapmıştı. Dımaşk alındığı sırada Mısır'daydı ${ }^{84}$ ve Kutuz’un şehre

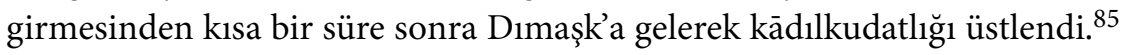

81 Ketboğa onu Kerek'in teslimi görüşmelerini yapmak üzere şehrin meliki Mugīs Ömer'e göndermişti (Yûnînî, Zeylü Mir'âti'z-zamân, I, 358).

82 İbnül-İmâd, Şezerâtü'z-zeheb, VII, 589. Ebû Şâme ve Sübkî ise onun Memlükler Bilâdüşşam'a hâkim olduklarında Dımaşk'ta bulunduğunu belirtmektedir (Ebû Şâme, Terâcim, s. 206; Sübkî, Tabakāt, VIII, 309-10).

83 Ebû Şâme, Terâcim, s. 206; Yûnînî, Zeylü Mirâti'z-zamân, I, 357.

84 Yûnînî, Zeylü Mirâti’z-zamân, IV, 123. Onun ne zaman ve niçin Dımaşk'tan ayrıldığı ve Mısır'a gittiği hakkında kaynaklarda bir bilgi bulunmamakla beraber Moğollar'ın Bilâdüşşam’a yönelmelerinin ardından Dımaşk’tan kaçanlar arasında yer almış olması muhtemeldir.

85 Ebû Şâme, Terâcim, s. 209. 
$\mathrm{Bu}$ noktada üzerinde durulması gereken hususlardan biri Moğollar tarafından kādılkudatllğa getirilen Ömer et-Tiflisî ve İbnü’z-Zekînin Moğollar geri çekildikten sonraki durumlarıdır. İki ismin sonraki dönemlerdeki hayatı VII. (XIII.) asırda Dımaşk ulemâsının sosyal ve siyasî konumu hakkında önemli ipuçları sunmaktadır. İsgal süresince halktan ve ümerâdan Moğollar ile iş birliği yapanlar daha sonra cezalandırılırken ulemâya karşı aynı tavrın takınılmamış olması dikkat çekicidir. Başta Ömer et-Tiflisî ve Muhyiddin İbnü’z-Zekî olmak üzere ulemâdan hiç kimse Moğol döneminde üstlendikleri ilmî ve idarî mansıplar sebebiyle daha sonra ne hainlikle ne de işbirlikçilikle suçlanmıştır. ${ }^{86}$ Her iki isim de daha sonra gittikleri Mısır'da medreselerde müderrislik yapmış, ders vermeye ve talebe yetiştirmeye devam etmiştir. Dahası Muhyiddin İbnü'z-Zekînnin çocukları da Memlükler'in erken döneminde kadılık, müderrislik, şeyhüşşüyûhluk, nâzırlık gibi çok sayıda mansıba getirilmiştir.

$\mathrm{Bu}$ isimlerin çalkantılı dönemden fazla etkilenmeden sonraki yıllarda ilmî faaliyetlerini devam ettirip mansıplar edinebilmeleri her şeyden önce hayatın her alanında söz sahibi olan ulemânın İslâm toplumundaki merkezî konumuyla yakından ilgilidir. Ulemânın bu durumu onları siyasî ve toplumsal tartışmaların üstünde bir konuma taşımaktadır. Diğer taraftan ele alınan dönemde Dımaşk ulemâsı tarafından sergilenen tavır, gayrimüslim bir yönetim altında yaşayan müslümanların hayatlarını İslâmî ölçüler içinde devam ettirme zorunluluğu karşısında bazı mansıplar kabul etmelerinin herhangi olumsuz bir tarafının olmadığına dair o dönemki dinî algıyı yansıtmaktadır. Moğol istilâsının İslâm dünyası için yeni bir tartışma konusu doğurduğuna değinilmişti. Bu süreçte işgal altındaki şehirlerde yaşayan müslümanların durumunun ne olacağı, bu beldelerin dârülislâm mı yoksa dârülharp mi sayılacağı, buralardaki müslümanların İslâm hâkimiyetindeki coğrafyalara hicret etmelerinin gerekip gerekmeyeceği ve Moğol hâkimiyetindeki şehirlerde özellikle ulemâ arasından çeşitli mansiplara getirilenlerin kâfir veya işbirlikçi sayılıp sayılmayacakları gibi konular birer tartışma alanına dönüşmüştür. İslâm dünyasında özellikle Moğol istilâsı döneminde çokça tartış1lan bu meselenin söz konusu algı̀ı inşa edecek şekilde ulemâ fetvalarına da yansıdığı görülmektedir. ${ }^{87}$

86 İçeriği bilinmese de Aynıcâlût Savaşı'ndan önce Mısır'dan hareket eden İslâm ordusu karşısında ne yapılacağı konusunda Ketboğa’nın istişare ettiği isimlerden birisinin Kadı Muhyiddin İbnü'z-Zekî olduğu belirtilmektedir. Fakat bu durum bile sonraki dönemde İbnü'z-Zekînin Moğol işbirlikçiliğiyle suçlanmasına sebep olmamıştır (Yûnînî, Zeylü Mirâtitz-zamân, I, 360).

$87 \mathrm{Bu}$ konuda biri Dımaşk’n işgalinden yaklaşık yüzyıl önce Hanefî fakihi Ebü’lKāsım es-Semerkandî (ö. 556/1161), diğeri ise yaklaşık kırk yıl sonra Hanbelî fakihi 


\section{Sonuç}

Hülâgû̉nun 9 Safer 658'de (25 Ocak 1260) Halep’i işgali ve ardından giriştiği katliam ve yağma Bilâdüşşam'daki diğer şehirlerde yaşayan sivil ve askerî grupların Moğollar’a karşı büyük bir korkuya ve tedirginliğe kapılmasına sebep olmuştur. Bu durum aralarında Dımaşk’n da bulunduğu bölgedeki diğer şehirlerin ciddi bir mukavemet göstermeden Moğollar’a teslim olmasında önemli rol oynamıştır.

Moğollar Dımaşk'ta müslümanların can ve mallarına yönelik hiçbir saldırıda bulunmamıştır. Bununla beraber Moğollar’ın Dımaşk’ da içine alan işgal faaliyetleri şehrin özellikle sosyal ve ilmî hayatına üç konuda etki etmiştir. Bunlardan ilki Moğol işgalinin müslümanlarla hıristiyanlar arasındaki ilişkilerde bir gerilim meydana getirmiş olmasıdır. Moğollar’n yerel işbirlikçi edinme politikasının bir parçası oldukları anlaşılan şehirdeki hıristiyanlar Moğol yöneticileri tarafından desteklenerek müslümanlara karşı bazı olumsuz faaliyetlere girişmişler, bu durum iki din mensupları arasındaki ilişkileri son derece olumsuz yönde etkilemiş, Moğollar’’n Aynicâlût'ta mağlûp edilmelerinden sonra ise Moğollar'la iş birliği yapan hıristiyanlar cezalandırılmıştır. İşgalin ikinci büyük etkisi ulemâ ve şehirdeki ilmî mansıplardaki değişimlerde kendisini göstermiştir. Moğollar’nn yerel ulemâ ile geliştirdikleri ilişkiler ulemâ arasında ilmî mansıplar üzerindeki var olan mücadeleyi tetiklerken, kādılkudatlığa getirilen âlimlerin bu karmaşa dönemini şehirdeki nüfuzlarını arttıracakları bir fırsat olarak kullanmaya çalıştıkları görülmektedir. Moğollar çekildikten sonra bu dönemde mansıp edinen ulemânın elindeki mansıplar geri alınmış, fakat aynı süreçte mansıp edinmek için girişimde bulunan ve çeşitli görevlere getirilen ulemâdan hiç kimse işbirlikçilikle veya ihanetle suçlanmamış, bu kimseler ilerleyen dönemlerde de mansıplar

Takıyyüddin İbn Teymiyye (ö. 728/1328) tarafından verilmiş dikkat çekici iki fetva, Moğol idaresinde mansıplara getirilen ulemânın diğer ulemâ tarafından nasıl algılandığına dair yol gösterici niteliktedir. Semerkandî, Karahıtaylar tarafından işgal edilen İslâm beldeleri ve buradaki müslümanlar hakkında, bu bölgelerde yargının İslâmî olması, müslümanların ibadetlerini serbestçe yapabilmeleri ve daha başka sebeplerden dolayı buraların dârülharp sayılamayacağını, her ne kadar yönetim İslâm dışı olsa da bu yönetim altında çeşitli görevler üstlenen kimselerin müslüman olduklarını, bu ülkelerde müslüman olduğunu söyleyen veya kelime-i şehâdeti okuyan herkesin müslüman sayılacağını, bunları mürtet veya kâfir diye nitelemenin büyük günah olduğunu, böyle bir tavrın İslâm toplumunu azaltmaya ve küfre teşvike yol açacağını söylemiştir. İbn Teymiyye ise Moğollar tarafından işgal edilen Mardin'de yaşayan müslümanlar hakkında verdiği fetvasında, işgal edilen veya yönetimin İslâmî olmadığı, fakat halkı müslüman bir ülkede yaşayıp gerektiğinde çeşitli görevler üstlenen kimseleri genel bir şekilde düşmanla iş birliği yapmış yahut dinden çıkmış gibi kabul etmenin haram olduğunu belirtmiştir (söz konusu fetvalar ve bu konuda ayrıntılı bilgi için bk. Özel, “Klasik İslâm Devletler Hukukunda Ülke Kavramı", s. 41-64). 
edinmeye ve ders verip talebe yetiştirmeye devam etmişlerdir. Bu durum VII. (XIII.) asırda ulemânın İslâm toplumundaki siyaset üstü ve merkezî konumuna işaret etmesi bakımından önemlidir. İşalin üçüncü önemli etkisi çok sayıda âlim ve önde gelen ismin Dımaşk'ı terketmesine sebep olmasıdır. $\mathrm{Bu}$ dönemde aralarında fakihlerin, tabiplerin, ediplerin, tüccarların ve sıradan halkın da bulunduğu çok sayıda kimse şehri terkederek başka yerlere göç etmiştir.

Moğollar'ın 658'deki (1260) işgalinden sonra da Moğol tehdidi hem yakın hem de uzak gelecekte Dımaşk üzerinde varlığını sürdürmüştür. ${ }^{88} \mathrm{Bu}$ durumun Eyyûbîler'in özellikle son yıllarında ilmî bir merkez olarak Dımaşk’ın önüne geçmeye başlayan Kahire'nin konumunu tahkim ettiği söylenebilir. Moğol işgalinin aynı zamanda Memlükler'in başşehri olan Kahire'nin ilerleyen yıllarda İslâm dünyasının en önemli ilim merkezi haline gelmesine etkisi, üzerinde durulması gereken bir konudur.

\section{Bibliyografya}

Alinge, Curt, Moğol Kanunları, çev. Çoşkun Üçok, Ankara: Ankara Üniversitesi Hukuk Fakültesi Yayınları, 1967.

Alshech, Eli, "Islamic Law, Practice, and Legal Doctrine: Exempting the Poor from the Jizya Under the Ayyubids (1171-1250)", Islamic Law and Society, 10/3 (2003): 363-74.

Amitai-Preiss, Reuven, Mongols and Mamluks: The Mamluk-Ilkhânid War 1260-1281, Cambridge: Cambridge University, 1996.

Avcı, Casim, "İbn Şeddâd, İzzeddin", Türkiye Diyanet Vakfi İslâm Ansiklopedisi (DİA), 1999, XX, 374-76.

Bezer, Gülay Öğ̈̈n, “Tuğteginliler”, DİA, 2012, XLI, 349-51.

Ebû Şâme el-Makdisî, Terâcimü ricâli'l-karneyni’s-sâdis ve’s-sâbi', nşr. Seyyid İzzet Attâr el-Hüseynî, Kahire: Dârü'l-kütübi'l-melikiyye, 1947.

Ebü'l-Fidâ, Târîh, haz. Mahmûd Deyyûb, I-II, Beyrut: Dârü'l-kütübi'l-ilmiyye, 1417/1997.

Gilbert, Joan Elizabeth, "The Ulama of Medieval Damascus and the International World of Islamic Scholarship” (doktora tezi), University of California-Berkeley, 1977.

88 Moğollar’ın Dımaşk'tan çekilmelerinden yaklaşık bir yıl sonra Musul'u işgal etmeleri Dımaşk’ta yeniden büyük bir endişe ve korkuya sebep olmuş, şehirdeki önde gelenlerden ve halktan pek çok kimse ellerindeki malları satarak Mısır'a kaçmaya karar vermiş, hatta bazıları yaşanabileceklere hazırlık olarak ailelerini önceden Mısır'a göndermiştir. Bu sırada şehirden insanlar kafileler halinde Mısır'a göç etmişlerdir (Ebû Şâme, Terâcim, s. 219; Makrîzî, Kitâbü’s-Sülûk, I/1-2, s. 473). 
Humphreys, R. Stephen, From Saladin to the Mongols, Albany: State University of New York, 1977.

İbn Ebû Usaybia, Uyûnü’l-enbầ fî tabakātil-etıbbâ’, nşr. Nizâr Rızâ, Beyrut: Dâru mektebeti'l-hayât, t.y.

İbn Hallikân, Vefeyâtü̉l-a'yân, nşr. İhsan Abbas, I-VIII, Beyrut: Dâru Sâdır, 1398/1978.

İbn Kādî Şühbe, Tabakātü̧ş-Şâfiiyye, nşr. Abdülhalîm Han, I-IV, Beyrut: Âlemü'l-kütüb, $1407 / 1987$.

İbn Kesîr, Ebü'l-Fidâ, el-Bidâye ve’n-nihâye, nşr. Abdullah b. Abdülmuhsin et-Türkî, I-XXI, Cîze: Hicr li’t-tıbâa ve’n-neşr, 1417-20/1997-99.

İbn Vâsıl, Müferricül-kürûb: Die Chronik des ibn Wāsil: Mufarriğ al-Kurūb fī Ahbār Banī Ayyūb, nşr. Mohamed Rahim, Wiesbaden: Harrassowitz Verlag, 2010.

İbnü'l-İmâd, Şezerâtü'z-zeheb, nşr. Abdülkādir el-Arnaût - Mahmûd el-Arnaût, I-X, Beyrut: Dâru İbn Kesîr, 1406-14/1986-93.

Jackson, Peter, The Mongols and the West, New York: Routledge, 2014.

Kafalı, Mustafa, “Cengiz Han”, DİA, 1993, VII, 367-69.

Kuşçu, Ayşe Dudu, Eyyûbî Devleti Teşkilatı, Ankara: Türk Tarih Kurumu, 2013.

Lane, George, Early Mongol Rule in Thirteenth Century Iran: A Persian Renaissance, London: Routledge Curzon, 2005.

Makrîzî, Kitâbü̉s-Sülûk li-ma'rifeti düveli’l-mülûk, nşr. Muhammed Mustafa Ziyâde, I-II, Kahire: Matbaatü'l-cenne, 1956.

Merçil, Erdoğan, “Şahne”, DİA, 2010, XXXVIII, 292-93.

Nuaymî, ed-Dâris fî târîhil-medâris, nşr. Ca'fer el-Hasenî, I-II, Kahire: Mektebetü’ssekāfeti'd-dîniyye, 1988.

Nüveyrî, Nihâyetüll-ereb fî fünûni'l-edeb, nşr. Müfîd Kumeyha v.dğr., I-XXXIII, Beyrut: Dârüll-kütübi'l-ilmiyye, 1424/2004.

Özaydın, Abdülkerim, “Aynicâlût Savaşı”, DİA, 1991, IV, 275-76.

Özel, Ahmet, “Klasik İslâm Devletler Hukukunda Ülke Kavramı ve Günümüzdeki Durum: İbn Teymiyye’nin Mardin Fetvası ile Benzeri Diğer Bazı Fetvalar”, Marmara Üniversitesi İlâhiyat Fakültesi Dergisi, 43 (2012): 41-64.

Reşîüddin Fazlullāh-1 Hemedânî, Câmiu't-tevârîh: İlhanlılar Kısmı, çev. İsmail Aka v.dğr., Ankara: Türk Tarih Kurumu, 2013.

Sa'dî, Abbas Fâzll, Yâkūt el-Hamevî, Beyrut: Dârü’t-Talîa, 1992.

Safedî, el-Vâfî bił'-vefeyât, nşr. Ahmed el-Arnaût - Türkî Mustafa, I-XXIX, Beyrut: Dâru ihyâi't-türâsi'l-Arabî, 1420/2000.

Spuler, Bertold, İran Moğolları, çev. Cemal Köprülü, Ankara: Türk Tarih Kurumu, 1957.

Sübkî, Tâceddin, Tabakātüşs-Şâfiiyyetỉl-kübrâ, nşr. Mahmûd Muhammed Tanâhî - Abdülfettâh Muhammed el-Hulv, I-X, Kahire: Matbaatü Îsâ el-Bâbî el-Halebî, 1383-96/ 1964-76. 
Şeşen, Ramazan, Salâhaddin Eyyûbî ve Devri, İstanbul: İslam Tarih, Sanat ve Kültürünü Araştırma Vakfi, 2000.

Şeşen, Ramazan, Salahaddin'den Baybars'a Eyyûbîler-Memluklar (1193-1260), İstanbul: İslam Tarih, Sanat ve Kültürünü Araştırma Vakfı, 2007.

Şirinov, Agil, “Tûsî, Nasîrüddin”, DİA, 2012, XLI, 437-42.

Tomar, Cengiz, "el-Melikü’n-Nâsır Yûsuf”, DİA, 2004, XXIX, 78-79.

Yılmaz, Harun, "Zengîler ve Eyyûbîler Döneminde Dımaşk’ta “Medrese" (1154-1260)" (doktora tezi), Marmara Üniversitesi Sosyal Bilimler Enstitüsü, 2014.

Yılmaz, Harun, “Meşîhatüşşüyûh'un Doğuşu ve Misır'da İki Hankah: Sa'îdü’s-Sü’adâ Siryâkûs", Tasavvuf, 15/34 (2014): 1-21.

Yûnînî, Kutbüddin, Zeylü Mirâti'-zamân, I-IV, Haydarâbâd: Dâiretü'l-maârifi'lOsmâniyye, 1374-80/1954-61.

Zehebî, Târîhu'l-İslâm: 651-660, nşr. Ömer Abdüsselâm Tedmürî, Beyrut: Dârüll-kitâbi'lArabî, 1419/1999.

\section{Dımaşk'ın En Zor Yılı: Şehrin Moğollar Tarafından İşgali (658/1260)}

Moğollar 656 (1258) yılında Bağdat’ı işgal ettikten sonra yönlerini daha batıdaki İslâm beldelerine çevirdiler. Bu sırada Bilâdüşşam’da Eyyûbîler, Mısır'da ise yaklaşık on yıl önce Eyyûbî hâkimiyetine son veren Memlükler hâkimdi. Moğollar’’n özellikle Halep’i ele geçirdiklerinde burada gerçekleştirdikleri katliam ve yağmalar bütün bölgede büyük bir korkuya ve endişeye sebep oldu. Bunun üzerine aralarında Bilâdüşşam’ın en önemli merkezi olan Dımaşk’ın da bulunduğu bölgedeki birçok şehir herhangi bir direniş göstermeden Moğollar'a teslim oldu. Dımaşk’’n Moğollar tarafından işgaliyle Eyyûbîler tarih sahnesinden çekildiler. Dımaşk ise Moğollar Aynicâlût Savaşında Memlükler tarafından mağlûp edilinceye kadar yaklaşık sekiz ay işgal altında kaldı. Moğol işgali, siyasî ve askerî alanda değişikliklere sebep olduğu kadar şehrin dinî, ilmî, ekonomik hayatında da önemli sonuçlar doğurdu. İşgal, Dımaşk’ta özellikle üç alanda önemli etkiler meydana getirdi: Müslüman-hıristiyan ilişkilerinde gerilimler ve yeni bir toplumsal düzen kurma teşebbüsü; mansıplar üzerinden birtakım ulemâ ile ilişkiler kurma ve ilmî mansıplardaki değişiklikler; güvenlik kaygısı sebebiyle aralarında ulemâdan isimlerin de bulunduğu çok sayıda insanın şehirden göçü. Moğol işgali sırasında Dımaşk'ta meydana gelen gelişmeler ile işgalin hemen ardından yaşanan restorasyon dönemini ele alan bu makale, ișgalin özellikle şehirdeki ulemâya etkisi üzerinde durmaktadır.

Anahtar kelimler: Dımaşk, Eyyûbîler, kādılkudatlık, Moğollar, ulemâ. 
